\title{
Holocene vegetation and climate changes in the central Mediterranean inferred from a high-resolution marine pollen record (Adriatic Sea)
}

\author{
N. Combourieu-Nebout ${ }^{1}$, O. Peyron ${ }^{2}$, V. Bout-Roumazeilles ${ }^{3}$, S. Goring ${ }^{4}$, I. Dormoy ${ }^{5}$, S. Joannin ${ }^{5,6}$, L. Sadori ${ }^{7}$, \\ G. Siani ${ }^{8}$, and M. Magny ${ }^{5}$ \\ ${ }^{1}$ CNRS/UVSQ/CEA-UMR 8212, LSCE, Gif sur Yvette, France \\ ${ }^{2}$ CNRS-UMR 5059 CNRS, CBAE-centre de Bio-Archéologie et d'Ecologie, Montpellier, France \\ ${ }^{3}$ CNRS-UMR 8217 Géosystèmes, Université Lille 1, France \\ ${ }^{4}$ Department of Geography, Univ. of Wisconsin-Madison, Wisconsin 53706, USA \\ ${ }^{5}$ CNRS-UMR 6249 CNRS, Laboratoire Chrono-Environnement, Besançon, France \\ ${ }^{6}$ School of Environment and Development, University of Manchester, Oxford Road, Manchester M13 9PL, UK \\ ${ }^{7}$ Dipartimento di Biologia Ambientale, Università La Sapienza, Roma, Italy \\ ${ }^{8}$ CNRS-UMR 8148, IDES, Département des Sciences de la Terre, Université Paris Sud, Orsay, France
}

Correspondence to: N. Combourieu-Nebout (nathalie.nebout@1sce.ipsl.fr)

Received: 26 March 2013 - Published in Clim. Past Discuss.: 5 April 2013

Revised: 10 July 2013 - Accepted: 12 July 2013 - Published: 2 September 2013

\begin{abstract}
The high-resolution multiproxy study of the Adriatic marine core MD 90-917 provides new insights to reconstruct vegetation and regional climate changes over the southcentral Mediterranean during the Younger Dryas (YD) and Holocene. Pollen records show the rapid forest colonization of the Italian and Balkan borderlands and the gradual installation of the Mediterranean association during the Holocene. Quantitative estimates based on pollen data provide Holocene precipitations and temperatures in the Adriatic Sea using a multi-method approach. Clay mineral ratios from the same core reflect the relative contributions of riverine (illite and smectite) and eolian (kaolinite) contributions to the site, and thus act as an additional proxy with which to evaluate precipitation changes in the Holocene.

Vegetation climate reconstructions show the response to the Preboreal oscillation (PBO), most likely driven by changes in temperature and seasonal precipitation, which is linked to increasing river inputs from Adriatic rivers recorded by increase in clay mineral contribution to marine sediments. Pollen-inferred temperature declines during the early-mid Holocene, then increases during the mid-late Holocene, similar to southwestern Mediterranean climatic patterns during the Holocene. Several short vegetation and climatic events
\end{abstract}

appear in the record, indicating the sensitivity of vegetation in the region to millennial-scale variability. Reconstructed summer precipitation shows a regional maximum $(170-200 \mathrm{~mm})$ between 8000 and 7000 similar to the general pattern across southern Europe. Two important shifts in vegetation occur at $7700 \mathrm{cal}$ yr BP (calendar years before present) and between 7500 and $7000 \mathrm{cal} \mathrm{yr} \mathrm{BP}$ and are correlated with increased river inputs around the Adriatic Basin respectively from the northern (7700 event) and from the central Adriatic borderlands (7500-7000 event). During the mid-Holocene, the wet summers lead to permanent moisture all year resulting in a homogeneous seasonal precipitation regime. After $6000 \mathrm{cal} \mathrm{yr} \mathrm{BP,} \mathrm{summer} \mathrm{precipitation} \mathrm{decreases} \mathrm{towards}$ present-day values while winter precipitation rises regularly showing the setting up of Mediterranean climate conditions.

Multiproxy evidence from core MD 90-917 provides a deeper understanding of the role of precipitation and particularly the seasonality of precipitation in mediating vegetation change in the central Mediterranean during the Holocene. 


\section{Introduction}

The Mediterranean is highly sensitive to climate change, and Mediterranean ecosystems, already widely affected by anthropogenic pressures, are likely to be strongly impacted by future warming and drought stresses. Precipitation changes are of particular concern for the region. Increasing dryness predicted by models for the Mediterranean will induce large water resource deficits and might threaten the region's habitability (Giorgi, 2006; IPCC, 2007; Giorgi and Lionello, 2008). While modern Mediterranean precipitation is controlled by the influences of both subtropical and midlatitudinal climatic belts, resulting in dry summers and rainy winters, climate in the Mediterranean has changed during the Holocene, providing an opportunity to study ecosystem response under a range of climate conditions. Thus, reconstructions of past vegetation and climate in the different basins of the Mediterranean will produce information allowing us to draw a general framework to understand regional change and the drivers of environmental and climate change across the whole basin.

The southern Adriatic, with its central location in the Mediterranean Basin, provides an excellent opportunity to record high-resolution vegetation changes in Italy and the Balkans in response to Holocene climate variability. In fact, central Mediterranean ecosystems are highly sensitive to climate changes and help to understand the climate connections and conflicting influences between northwestern and southeastern atmospheric systems and their relative roles in mediating precipitation and runoff during the Holocene.

Holocene vegetation change in the central Mediterranean has been widely investigated using continental and marine records (e.g. Watts et al., 1996; Combourieu-Nebout et al., 1998; Jahns and van den Bogaard, 1998; Magri, 1999; Magri and Sadori, 1999; Allen et al., 2002; Oldfield et al., 2003; Drescher-Schneider et al., 2007; Piva et al., 2008; Kotthoff et al., 2008a, b, 2011; Di Donato et al., 2008; Di Rita and Magri, 2009; Joannin et al., 2012, 2013; Di Rita et al., 2013). Although these records vary in temporal and taxonomic resolution, they show a general pattern of forest expansion linked to warming climates in the Holocene, as well as the influence of millennial-scale climate variability on continental paleoenvironments. Most records from the central Mediterranean divide the Holocene into three phases, similar to those in other regions of the Mediterranean (e.g. Jalut et al., 2000, 2009; Finné et al., 2011) with boundaries that have been recently refined by Walker et al. (2012): (i) an early Holocene humid period from 11700 to 8200 cal yr BP (calendar years before present); (ii) a mid-Holocene transitional period from 8200 to $4200 \mathrm{cal} \mathrm{yr} \mathrm{BP}$; and, (iii) a late-Holocene period of aridification following $4200 \mathrm{cal} \mathrm{yr}$ BP. Climate reconstructions from Lake Accesa (northcentral Italy) distinguish two distinct intervals based on precipitation and emphasize the role of the seasonality during the Holocene (Peyron et al., 2011). Given the scarcity of reliable high-resolution pollen records in the central Mediterranean and the peculiarities of this region, new evidence is needed to better understand the climate changes and the climate processes in this area.

The new pollen record from the marine MD 90-917 core provides new insights into vegetation and climate changes for the central Mediterranean. This study, part of the French multi-proxy project LAMA, provides a new understanding of the links between hydrological variability, climate and vegetation in the central Mediterranean by bringing together continental and marine data to produce an integrated interpretation of the paleoenvironmental interpretation of Holocene climate changes. This paper investigates the impacts of long-term and millennial-scale climate variability during the Holocene through temperature and precipitation stresses on Italian and Balkan vegetation. By examining the clay fraction ratios from the same core we will be able to discuss patterns of local and regional runoff linked to precipitation and seasonality changes.

\section{Lithology and age model}

Core MD 90-917 $\left(41^{\circ} \mathrm{N}, 17^{\circ} 37^{\prime} \mathrm{E}\right)$ was collected in the Adriatic Sea by the R/V Marion Dufresne at a depth of $1010 \mathrm{~m}$ (Fig. 1). The core is described more fully in CombourieuNebout et al. (1998) and Siani et al. (2004, 2010). Sediments are composed of $21 \mathrm{~m}$ of clay, interrupted by two black layers corresponding to the deposition of the $\mathrm{S} 1$ sapropel in two levels, S1a and S1b respectively, at 249-255 cm and 229$239 \mathrm{~cm}$ downcore (Siani et al., 2004). The pollen record presented in this paper focuses on the upper $3.3 \mathrm{~m}$ of the core.

The age model of the core was previously given in Siani et al. (2010) and uses tephra layers and 21 AMS (accelerator mass spectrometry) ${ }^{14} \mathrm{C}$ dates performed on monospecific planktonic foraminifera. The conventional radiocarbon ages have been subsequently converted into calendar ages, based on INTCAL04 (Reimer et al., 2004) using the ${ }^{14} \mathrm{C}$ calibration software CALIB 6. The calibration integrates a marine ${ }^{14} \mathrm{C}$ reservoir age correction $R(t)$ at $390 \pm 85 \mathrm{yr}$ according to Siani et al. (2000, 2001). For this paper, only 13 AMS ${ }^{14} \mathrm{C}$ are used and provide a reliable age model for the last $13000 \mathrm{cal}$ yr BP (Table 1).

\section{Present-day environmental settings}

\subsection{Climate and atmospheric circulation pattern}

Atmospheric circulation in the Adriatic is controlled by two dominant climatic systems. In the winter the Eurasian High extends to the southwest. The Eurasian High retreats northward in the summer and is replaced by the northeastward expansion of the Azores High. This pattern results in a typically Mediterranean climate (Fig. 1): winters are generally stormy and cool/cold while summers are warm/hot and dry. Spring climate in the region is generally long, characterized 

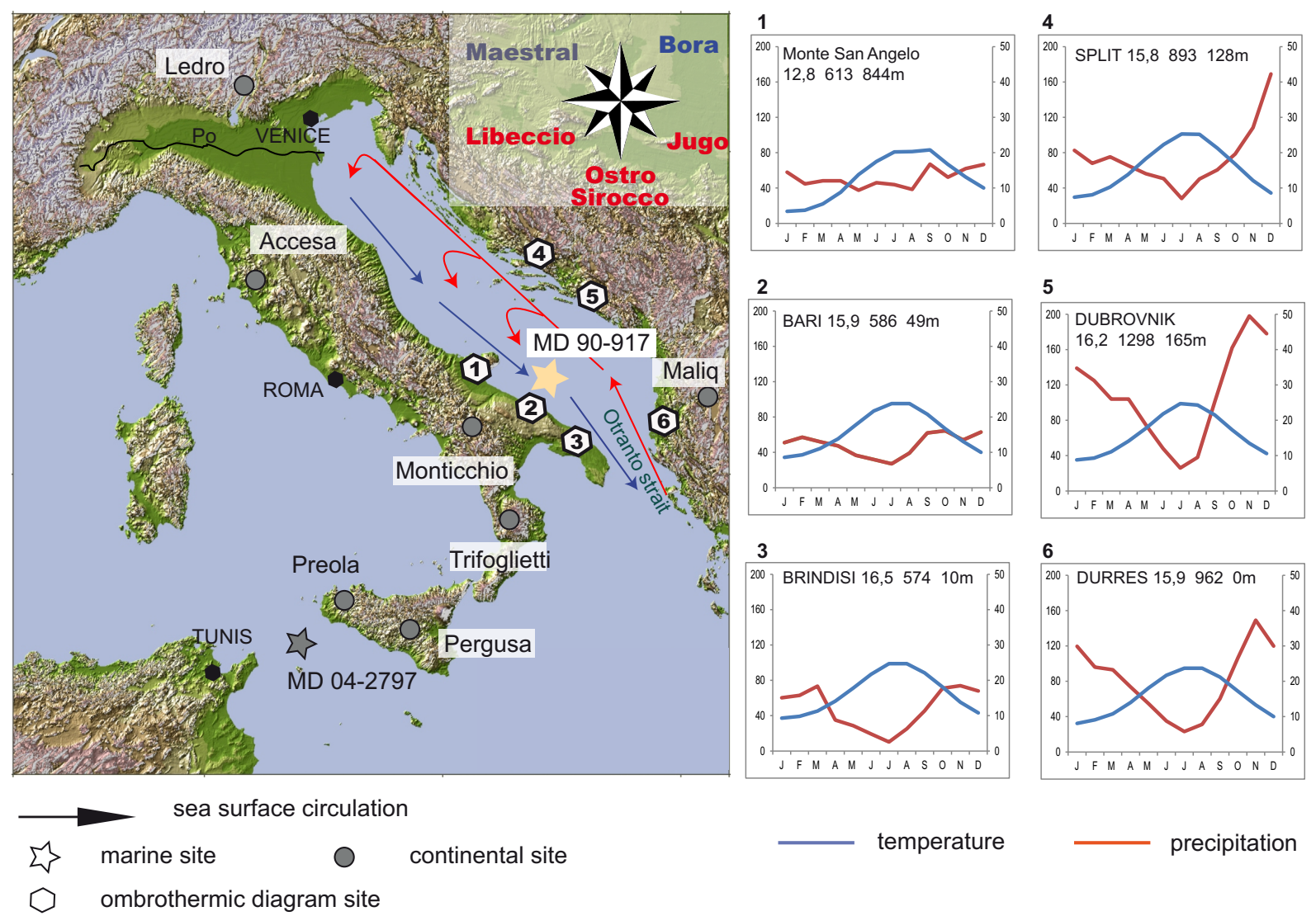

temperature

precipitation

Fig. 1. Location of core MD 90-917. On the map is indicated sea surface circulation in Adriatic Sea and winds blowing over the Adriatic Basin. A selection of ombrothermic diagrams is presented on the right for the surrounding borderlands to show the climate of the studied area (Walter et al., 1975; New et al., 2000, New LoCCllim software). For each ombrothermic diagram, near or below the site name is noted the annual mean temperature, the total annual precipitation and the altitude of the site. For each ombrothermic diagram, the left axis corresponds to precipitation values and the right axis to the temperature value. Red arrows represent the south-north sea surface water inflow; blue arrows draw the north-south sea surface outflow.

by fluctuating weather while autumn is very short with an abrupt transition toward winter. The length and intensity of summer dryness increases southwards across the Adriatic; total annual precipitation grades from a maximum in the east to a minimum in the west (Fig. 1). The mountainous regions in the Adriatic Basin may show patterns that are dramatically different than their surroundings. In the Apennines or Dinarides, temperatures decrease and precipitation increases according to altitudinal elevation.

A number of winds blow over the central Mediterranean (Fig. 1). The bora is a cold wind that commonly blows from the north and northeast during winter. The mistral (Italian: maestral) is a northwestern wind that blows from spring to autumn, more often in summer with decreasing strength to the south. The sirocco blows from the south from autumn to spring, bringing dust from North Africa. The ostro is a southerly wind often identified with the sirocco. The jugo is an east to southeast dry wind that blows most often in the winter. The west to southwest wind called libeccio blows year-round but rarely reaches the Adriatic Basin.

\subsection{Hydrology of Adriatic Basin}

The hydrology of the Adriatic Sea is seasonally controlled by winds and river inputs. Sea surface circulation follows a general pattern with a south-north inflow from the Ionian Sea through the Otranto Basin. Flow progresses counterclockwise from the east coast of the Adriatic to the north-south outflow along the west coast of the basin. The outflow is strengthened by the discharge from the Po River as well as from small rivers running into the Adriatic along the eastern Italian coast (Fig. 1). The eastern Balkans do not contribute significantly to fresh water inputs into the Adriatic since rivers in the region have short runs with low flow, producing only local effects near the coast. Thus, contributions to the fresh water and nutrient inputs in the Adriatic Basin are largely derived from Italian river systems dominated by Po River discharges. The Po is primarily fed by snowmelt in the spring and high runoff in the autumn, particularly in the northern reaches of the watershed (Cattaneo et al., 2003; 
Table 1. Age model for core MD 90-917, AMS ${ }^{14} \mathrm{C}$ ages and corresponding calendar ages from INTCAL04 (Reimer et al., 2004) integrating ${ }^{14} \mathrm{C}$ reservoir age correction $R(t)$ at $390 \pm 85 \mathrm{yr}$ BP (Siani et al., 2000, 2001).

\begin{tabular}{rlrrr}
\hline Depth $(\mathrm{cm})$ & Species & ${ }^{14} \mathrm{C}$ age BP $(\mathrm{yr})$ & Error $\pm 1 \sigma$ & Cal age BP $(\mathrm{yr})$ \\
\hline $0-2$ & G. bulloides & 1010 & 60 & $555-609$ \\
$140-142$ & G. ruber & 4180 & 70 & $4082-4290$ \\
$167-169$ & G. ruber & 4750 & 70 & $4855-4986$ \\
$175-177$ & G. bulloides & 5000 & 70 & $5344-5466$ \\
$190-192$ & G. bulloides & 5680 & 70 & $5990-6128$ \\
$230-232$ & G. bulloides & 6920 & 90 & $7413-7511$ \\
$240-242$ & G. bulloides & 7930 & 80 & $8171-8340$ \\
$250-252$ & G. ruber & 8170 & 70 & $8390-8482$ \\
$275-277$ & G. bulloides & 10390 & 90 & $11304-11624$ \\
$295-297$ & G. bulloides & 10800 & 90 & $12116-12399$ \\
$305-307$ & G. bulloides & 10830 & 90 & $12225-12406$ \\
$315-317$ & G. bulloides & 11140 & 90 & $12721-12853$ \\
$335-337$ & G. bulloides & 11520 & 100 & $12939-13114$ \\
\hline
\end{tabular}

Frignani et al., 2005; Orange et al., 2005; Palinkas and Nittrouer, 2007).

\subsection{Present-day vegetation}

Vegetation is organized along altitudinal belts on the Adriatic borderlands according to the ecological requirements of the plants. Four dominant vegetation types exist in Italy, associated with increasing elevations from the coast to high elevations: the thermo-, meso-, supra- and oromediterranean vegetation types. The thermomediterranean belt is dominated by Olea and Ceratonia at the lowest elevations; the mesomediterranean belt is composed largely of Quercus ilexcoccifera forest; supramediterranean $(600-800 \mathrm{~m})$ vegetation is defined by deciduous oak forest with Quercus and Carpinus; and, at the highest elevations, the oromediterranean belt is characterized by an Abies and Fagus sylvatica forest (Ozenda, 1975).

The Dalmatian vegetation has been described by Horvat et al. (1974) and Polunin (1980). Adriatic islands, covered by Quercus ilex forest are now largely colonized by pine forest. Inland, forests are dominated by supramediterraean vegetation at higher altitudes, composed of deciduous trees such as Carpinus, Ostrya, Fraxinus and Quercus. At higher elevation, where summer precipitation is higher, mountain forests are mainly dominated by Fagus, Abies alba and Picea.

Natural vegetation in the region has been affected by human pressure in recent times; forest clearance and intensive farming often result in landscapes of bush-wood or open vegetation.

\section{Methods}

\subsection{Pollen record}

A pollen record spanning from Last Glacial Maximum to Holocene was published by Combourieu-Nebout et al. (1998). This new analysis includes 51 additional counts, improving the temporal resolution of the Holocene section of this core. The new pollen data corresponds to time sampling intervals of from 15 to $500 \mathrm{yr}$ with an average of $140 \mathrm{yr}$. Samples of the upper $80 \mathrm{~cm}$ were pollen poor and did not provide reliable data, possibly as a result of poor pollen preservation. The proposed pollen record, from 3 to $0.8 \mathrm{~m}$ depth, highlights vegetation changes at the end of deglaciation and during most of the Holocene, from $\sim 13000$ to $\sim 2500 \mathrm{cal} \mathrm{yr} \mathrm{BP.}$

Pollen was obtained from marine sediments following a previously described standard protocol (e.g. Faegri and Iversen, 1964; Combourieu-Nebout et al., 1998). Samples underwent successive treatments with $\mathrm{HCl}$ and $\mathrm{HF}$ acids and several sievings to obtain concentrated pollen residues. Pollen grains were counted on slides with an Olympus light microscope at x500 magnification. Between 150 and 300 grains were counted in each sample, based on pollen concentration. Pinus is over-represented in most marine samples. Because of over-representation of Pinus in the MD 90-917 pollen samples, all assemblages had at least 100 non-Pinus counts (Heusser and Balsam, 1977, Turon, 1984).

Pollen diagrams use sums that exclude Pinus pollen. Pinus percentages were calculated using the total sum of identified grains. Pteridophyta percentages are reported using the total sum of all identified pollen grains and Pteridophyta. Pollen zones were visually determined and confirmed using cluster analysis (CONISS software, Grimm, 1987) (Fig. 2a, b).

Fossil pollen assemblages from the MD 90-917 core show similarities to a range of vegetation types from semi-desert to 
(a) MD 90917

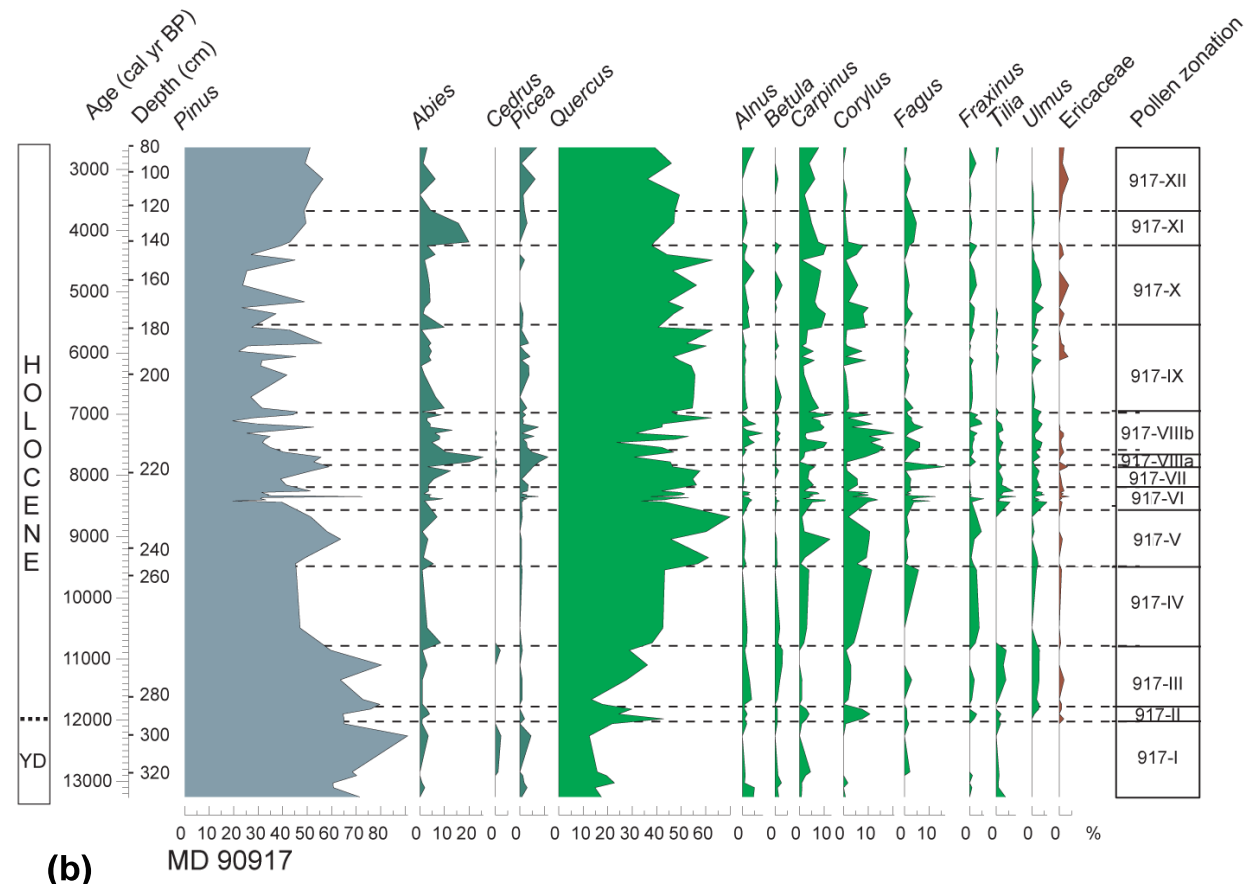

(b)
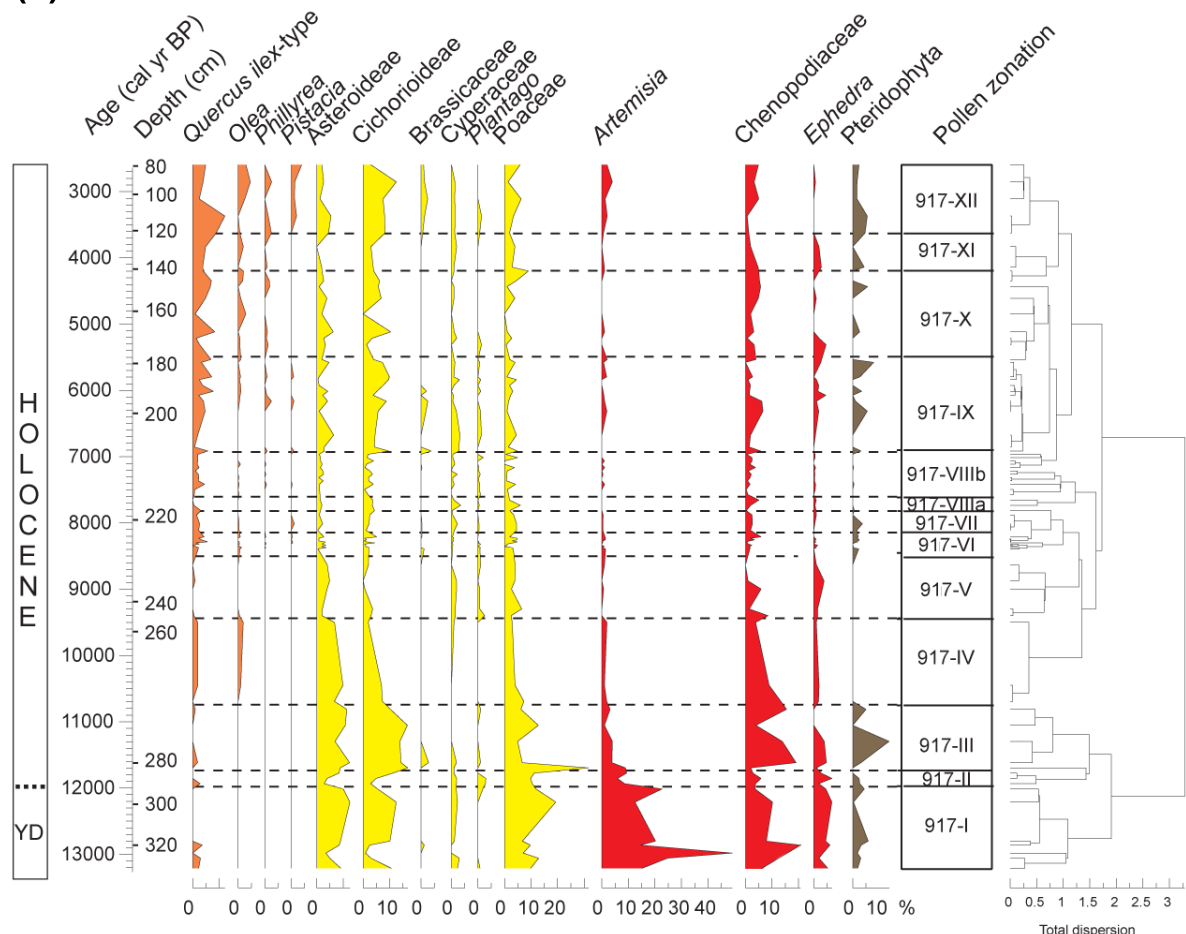

Fig. 2. Pollen diagram of the core MD 90-917. (a) arboreal taxa; (b) Mediterranean and herbaceous taxa. Pollen percentages are calculated on a sum excluding Pinus; Pinus percentages are calculated on the total pollen sum. Pteridophyta percentages are calculated on the total pollen sum. Pollen curves are presented in calendar yr BP (correspondence between age and depth is presented on the left). On the right of the diagram are represented the pollen zones and results of the cluster analysis (CONISS software, Grimm, 1987). 
Table 2. Short description of the pollen zonation of the MD 90-917 pollen diagram.

\begin{tabular}{|c|c|c|c|c|c|}
\hline Pollen zone & Interval $\mathrm{cm}$ & Age kyr & Pollen zone signature & Main biome & Climate \\
\hline MD 90 917-XII & $80-120$ & $2641-3671$ & $\begin{array}{l}\text { Pinus }(50 \%), \downarrow \text { Abies }(<4 \%) \text { and Picea }(<6 \%) \text { Quercus } \\
(45 \%) \text {, Carpinus }(6 \%) \text { Corylus in low percentages, } \uparrow \text { Fagus }(4 \%) \\
\text { Mediterranean taxa, Q. ilex }(\uparrow 12 \%) \text {, Olea }(3-4 \%) \text { and Pistacia } \\
(\uparrow 4 \%) \uparrow \text { Cichoriodeae; } \uparrow \text { Artemisia }(15 \%),\end{array}$ & $\begin{array}{l}\text { Warm temperate } \\
\text { Mediterranean oak } \\
\text { forest }\end{array}$ & $\begin{array}{l}\text { Warm and humid } \\
\text { stability in } T^{\circ} \uparrow \\
\text { seasonal } P \text { mm }\end{array}$ \\
\hline MD90 917-XI & $128-140$ & $3877-4186$ & $\begin{array}{l}\text { Pinus }(50 \%), \uparrow \text { Abies }(<15 \%) \text {, Picea }(3 \%) \text { Quercus }(40 \%) \text {, } \\
\text { Carpinus }(6 \%) \text {, Corylus and Fagus in low percentages, Mediter- } \\
\text { ranean taxa in low percentages, Q. ilex }(4 \%)\end{array}$ & Cool mixed forest & $\begin{array}{l}\text { Cool and relatively } \\
\text { humid }\end{array}$ \\
\hline MD90 917-X & $142-179$ & $4244-5579$ & $\begin{array}{l}\text { Pinus low (20-40\%), low percentages in Abies and Picea } \\
(<6 \%) \downarrow \text { Quercus }(45 \%), \quad \uparrow \text { Carpinus }(\uparrow 10 \%) \text { and Corylus } \\
(\uparrow 10 \%) \quad \text { Mediterranean taxa in stable percentages Herbs in } \\
\text { stable percentages; slight increase in steppic taxa }(5-10 \%)\end{array}$ & $\begin{array}{l}\text { Warm temperate } \\
\text { oak forest }\end{array}$ & $\begin{array}{l}\text { Warm and humid } \\
\text { stability in } \\
T^{\circ} P \text { mm } \\
\text { slight decrease }\end{array}$ \\
\hline MD90 917-IX & $180-220$ & $5623-6960$ & $\begin{array}{l}\text { Pinus low }(20-40 \%) \text {; low percentages in Abies and Picea } \\
(<6 \%) \text { Temperate trees stable, } \uparrow \text { Quercus }(\uparrow 45-65 \%), \downarrow \text { Carpi- } \\
\text { nus }(\sim 5 \%) \text { and Corylus }(\sim 5 \%), \quad \uparrow \text { Mediterranean taxa, Q. ilex } \\
(6-7 \%) \text {, Olea, Phillyrea and Pistacia } \uparrow \text { in herbs; Cichoriodeae } \\
(5-10 \%) \text {; steppic taxa low }\end{array}$ & $\begin{array}{l}\text { Warm temperate } \\
\text { oak forest }\end{array}$ & $\begin{array}{l}\text { Warm and humid } \\
\text { stability in } T^{\circ} \text { and } \\
P \text { mm slightly } \\
\text { reincrease }\end{array}$ \\
\hline MD90 917-VIIIb & $221-232$ & $7010-7620$ & $\begin{array}{l}\text { Pinus }(20-50 \%), \downarrow \text { Abies }(<10 \%) \text { and Picea }(<5 \%) \text { decrease } \\
\uparrow \text { Temperate trees, Quercus stable }(<45 \%), \quad \text { Corylus }(5- \\
20 \%) \text {, Carpinus }(4-10 \%) \text {, Fagus }(\uparrow 5 \%) \text {, Ulmus, }(\uparrow 5 \%) \text {, Alnus } \\
(3-8 \%) \text {, Mediterranean taxa stable }(Q . \text { ilex mainly, Olea and Pista- } \\
\text { cia presence) } \downarrow \text { Herbs (Asteraceae }<5 \% \text {, Poaceae }<5 \%) \text {, steppic } \\
\text { taxa low }(10 \%)\end{array}$ & $\begin{array}{l}\text { Warm temperate } \\
\text { oak forest }\end{array}$ & $\begin{array}{l}\text { Warm and humid } \\
\text { increase in } T^{\circ} \text { and } \\
P \text { mm slight de- } \\
\text { crease }\end{array}$ \\
\hline MD90 917-VIIIa & $233-234$ & $7700-7779$ & $\begin{array}{l}\text { Pinus }(50 \%), \uparrow \text { Abies }(\uparrow 25 \%) \text { and Picea }(\uparrow 11 \%) \downarrow \text { Temperate } \\
\text { trees, Quercus }(<45 \%) \text {, Corylus, Carpinus absent, Fagus }(\uparrow \\
10 \%) \text {, Mediterranean taxa low Herbs low, steppic taxa low (slight } \\
\uparrow \text { Chenopodiaceae; } 2-5 \%)\end{array}$ & Cool mixed forest & Cool and humid \\
\hline MD90 917-VII & $235-238$ & $7859-8058$ & $\begin{array}{l}\text { Pinus }(30-60 \%) \text {; Abies and Picea low Temperate trees: Quercus } \\
(30-60 \%), \quad \text { Corylus }(<5 \%) \text {, Carpinus }(4 \%) \text {, Fagus }(\uparrow 10 \%) \\
\text { Mediterranean taxa low }(Q . \text { Ilex mainly, Olea presence) } \downarrow \text { Herbs } \\
(\text { Asteraceae }<5 \% \text {, Poaceae }<5 \%) \text {, steppic taxa nearly absent }\end{array}$ & $\begin{array}{l}\text { Warm temperate } \\
\text { oak forest }\end{array}$ & $\begin{array}{l}\text { Warm and humid } \\
\text { Max } T^{\circ} \text { and } P \text { mm } \\
\text { slight reincrease }\end{array}$ \\
\hline MD90 917-VI & $239-250$ & $8157-8456$ & $\begin{array}{l}\text { Pinus }(30-60 \%) \text {; Abies and Picea low Temperate trees: Quer- } \\
\text { cus }(40 \%) \text {, Corylus }(5-10 \%) \text {, Carpinus }(4-10 \%) \text {, Fagus }(\uparrow 8 \%) \\
\text { Mediterranean taxa } \uparrow(Q . \text { ilex mainly, Olea and Pistacia presence) } \\
\downarrow \text { Herbs (Asteraceae }<5 \% \text {, Poaceae }<5 \%) \text {, steppic taxa low }\end{array}$ & $\begin{array}{l}\text { Warm temperate } \\
\text { oak forest }\end{array}$ & $\begin{array}{l}\text { Warm and humid } \\
\text { Max } T^{\circ} \text { and } P \text { mm } \\
\text { slight decrease }\end{array}$ \\
\hline MD90 917-V & $252-258$ & $8678-9445$ & $\begin{array}{l}\text { Pinus ( around 50\%), Abies and Picea low } \uparrow \text { Temperate trees, } \\
\text { maximum Quercus }(45-70 \%) \text {, Corylus }(5-10 \%) \text {, Carpinus }(2- \\
10 \%) \text { Mediterranean taxa low (Q. ilex only) } \downarrow \text { Herbs (Asteraceae } \\
<5 \% \text {, Poaceae }<5 \% \text { ) and steppic taxa low }\end{array}$ & $\begin{array}{l}\text { Warm temperate } \\
\text { oak forest }\end{array}$ & $\begin{array}{l}\text { Warm and humid - } \\
\text { Max } T^{\circ} \text { and } P \text { mm }\end{array}$ \\
\hline MD90 917-IV & $259-269$ & $9546-10737$ & $\begin{array}{l}\text { Large decrease in Pinus }(<50 \%) \text {, Abies and Picea nearly absent } \\
\text { Increase in temperate trees, Quercus }(40 \%) \text {, Corylus }(5-10 \%) \text {, } \\
\text { Carpinus }(2-4 \%) \text { Mediterranean taxa low }(Q \text {. ilex and first oc- } \\
\text { currence in Olea) } \downarrow \text { Herbs (Asteraceae }<12 \% \text {, Poaceae }<7 \%) \text {, } \\
\text { steppic taxa very low }\end{array}$ & $\begin{array}{l}\text { Warm temperate } \\
\text { oak forest }\end{array}$ & $\begin{array}{l}\text { Progressive } \uparrow \\
T^{\circ} \text { and } P \mathrm{~mm}\end{array}$ \\
\hline MD90 917-III & $270-282$ & $10858-11742$ & $\begin{array}{l}\text { Pinus abundant }(60-80 \%), \text { Abies and Picea percentages low } \\
\text { Quercus }(20-40 \%), \quad \downarrow \text { Corylus and Carpinus, slight } \uparrow \text { Alnus, Be- } \\
\text { tula, Tilia } \uparrow \text { Herbs (Asteraceae } 20 \%), \uparrow \text { Chenopodiaceae }>10 \%\end{array}$ & $\begin{array}{l}\text { Grassland mixed to } \\
\text { open oak forest }\end{array}$ & $\begin{array}{l}\text { Cool and } \\
\text { moderately dry }\end{array}$ \\
\hline MD90 917-II & $284-288$ & $11821-11980$ & $\begin{array}{l}\text { Pinus abundant }(65-75 \%), \text { Abies and Picea percentages low } \\
\uparrow \text { Quercus }(15-40 \%) \text {, Corylus }(\uparrow 10 \%) \text {, Carpinus }(3 \%) \downarrow \text { Herbs } \\
\text { (Asteraceae }<20 \% \text {, Poaceae around } 10 \%), \downarrow \text { steppic taxa low }\end{array}$ & $\begin{array}{l}\text { Open Warm mixed } \\
\text { forest }\end{array}$ & $\begin{array}{l}\text { Slight increase in } \\
T^{\circ} \text { and } P \mathrm{~mm}\end{array}$ \\
\hline MD90 917-I & $290-350$ & $12060-13257$ & $\begin{array}{l}\text { Pinus abundant }(65-90 \%) \text {, Abies and Picea percentages low } \\
\text { Low percentages in temperate trees, Quercus }<20 \% \text {, Alnus, } \\
\text { Betula, Carpinus present Herbs abundant, Asteraceae } 10-20 \% \text {, } \\
\text { Poaceae around } 10 \% \text { Steppic taxa abundant (Artemisia } 15 \% \text {, } \\
\text { Chenopodiaceae } 10 \% \text {, Ephedra up to } 7 \% \text { ) }\end{array}$ & Steppe & Cold and dry \\
\hline
\end{tabular}


mountain deciduous and coniferous forest. The interpretation of these assemblages follows the modern plant-climate relationships in Eurasia and northern Africa (Woodward, 1987; Peyron et al., 1998).

\subsection{Pollen-based climate reconstructions}

To obtain a robust quantitative reconstruction of Holocene climate changes in the Adriatic Sea, two methods have been used to reconstruct climate parameters: modern analogues technique (MAT: Hutson, 1980; Guiot, 1990) and weighted average partial least squares regression (WAPLS: Ter Braak and Juggins, 1993). Both methods have been used extensively for the Holocene climate reconstruction from terrestrial and marine pollen records located in the Mediterranean region (e.g. Davis et al., 2003; Pross et al., 2009; Peyron et al., 2011, 2013; Joannin et al., 2012; Kotthoff et al., 2008a, b; Combourieu-Nebout et al., 2009; Dormoy et al., 2009; Desprat et al., 2013; Sadori et al., 2013) with results that are generally supported by other independent proxies (e.g. lake levels, alkenones, charcoals, etc.) and other regional records.

Like most classic pollen-based climate reconstruction techniques, MAT aims to quantitatively reconstruct past climate from fossil assemblages based on the present-day environment. MAT compares past assemblages to modern pollen assemblages without requiring real statistical calibration, using squared-chord distance to determine the degree of similarity between samples with known climate parameters (modern pollen samples) to a sample for which climate parameters are to be estimated (fossil pollen sample). In contrast to the MAT, the WAPLS is a true transfer function that requires a statistical calibration between environmental variables (climate parameters) and modern pollen assemblages. WAPLS is a common regression method which supposes that the relationships between pollen percentages and climate parameters are unimodal. More details on the MAT and on the WAPLS are given in Peyron et al. (2013).

Both methods are calibrated using the high-quality and taxonomically consistent dataset compiled by Dormoy et al. (2009). This dataset contains more than 2000 samples from the Mediterranean region to which were added 26 modern surface samples from around Lake Trifoglietti (Calabria, southern Italy) collected by Joannin et al. (2012), and from around Mount Altesina and Lake Preola (Sicily). Pi$n u s$ pollen was removed from the modern and fossil samples because of its over-representation in marine pollen assemblages. In this study, the quantitative climate reconstructions for the core MD 90-917 were performed using annual (TANN), coldest month (MTCO) and warmest month (MTWA) temperature, and annual (PANN), spring (Pspr), summer (Psum), autumn (Paut) and winter (Pwin) precipitation to emphasize changes in seasonality. Results are expressed as reconstructed values and anomalies (reconstructed values minus present-day values) (Fig. 3).

\subsection{Sediment clay fraction}

Samples were prepared following standard protocols described in Bout-Roumazeilles et al. (2007). All samples were first decalcified with $0.2 \mathrm{~N}$ hydrochloric acid. Excess acid was removed by repeated centrifugations. The claysized fraction $(<2 \mu \mathrm{m})$ was isolated by settling, and oriented on glass slides (oriented mounts). Three XRD (Xray diffraction) determinations were performed: (a) untreated sample, (b) glycolated sample (after saturation for $12 \mathrm{~h}$ in ethylene glycol), and (c) sample heated at $490{ }^{\circ} \mathrm{C}$ for two hours. The analyses were run on a Philips PW 1710 Xray diffractometer, between 2.49 and $32.5^{\circ}$. Each clay mineral is characterized by its layer plus interlayer interval as revealed by XRD analysis. Smectite is characterized by a peak at $14 \AA$ on the untreated sample test, which expands to $17 \AA$ after saturation in ethylene glycol and retracts to $10 \AA$ after heating. Illite presents a basal peak at $10 \AA$ on the three tests (natural, glycolated, and heated). Kaolinite is characterized by peaks at 7 and $3.57 \AA$ on the untreated sample and after saturation in ethylene glycol. Both peaks disappear or are strongly reduced after heating. Semiquantitative estimation of clay mineral abundances, based on the pseudo-voigt deconvolution for the doublet kaolinitechlorite $(3.57 \AA-3.53 \AA)$, was performed using the software MacDiff developed by Petschick (2001). Here we use the illite to kaolinite and smectite to kaolinite ratios in order to evaluate the balance between inputs from rivers, respectively Po River (illite) and eastern Apennine rivers (smectite), versus eolian inputs from the south (kaolinite). These ratios are calculated using the semi quantitative estimation of each clay mineral.

\section{Origin of the continental proxy data}

\subsection{Pollen inputs}

Paleoenvironmental interpretation of the changes depicted in the marine pollen assemblages is based on the assumption that the pollen signal recorded in the marine core reflects the regional vegetation across an area of several hundred square kilometers (Heusser and Balsam, 1977; Dupont and Wyputta, 2003; Hooghiemstra et al., 1992, 2006). Pollen composition in deep basins of the Adriatic Sea must then be strongly affected by the dominant winds and hydrological currents that bring pollen grains from their source to the site in which they are ultimately carried.

Most pollen grains within the MD 90-917 core, and especially arboreal pollen from Quercus, Quercus ilex, Carpinus, Corylus, Fraxinus, and Abies are likely to originate on either coast of the Adriatic Basin given similarities in the modern vegetation community structure between coasts (Ozenda, 1975; Horvat et al., 1974). However, natural stands of Olea are nearly absent on the Dalmatian coast today and are only 

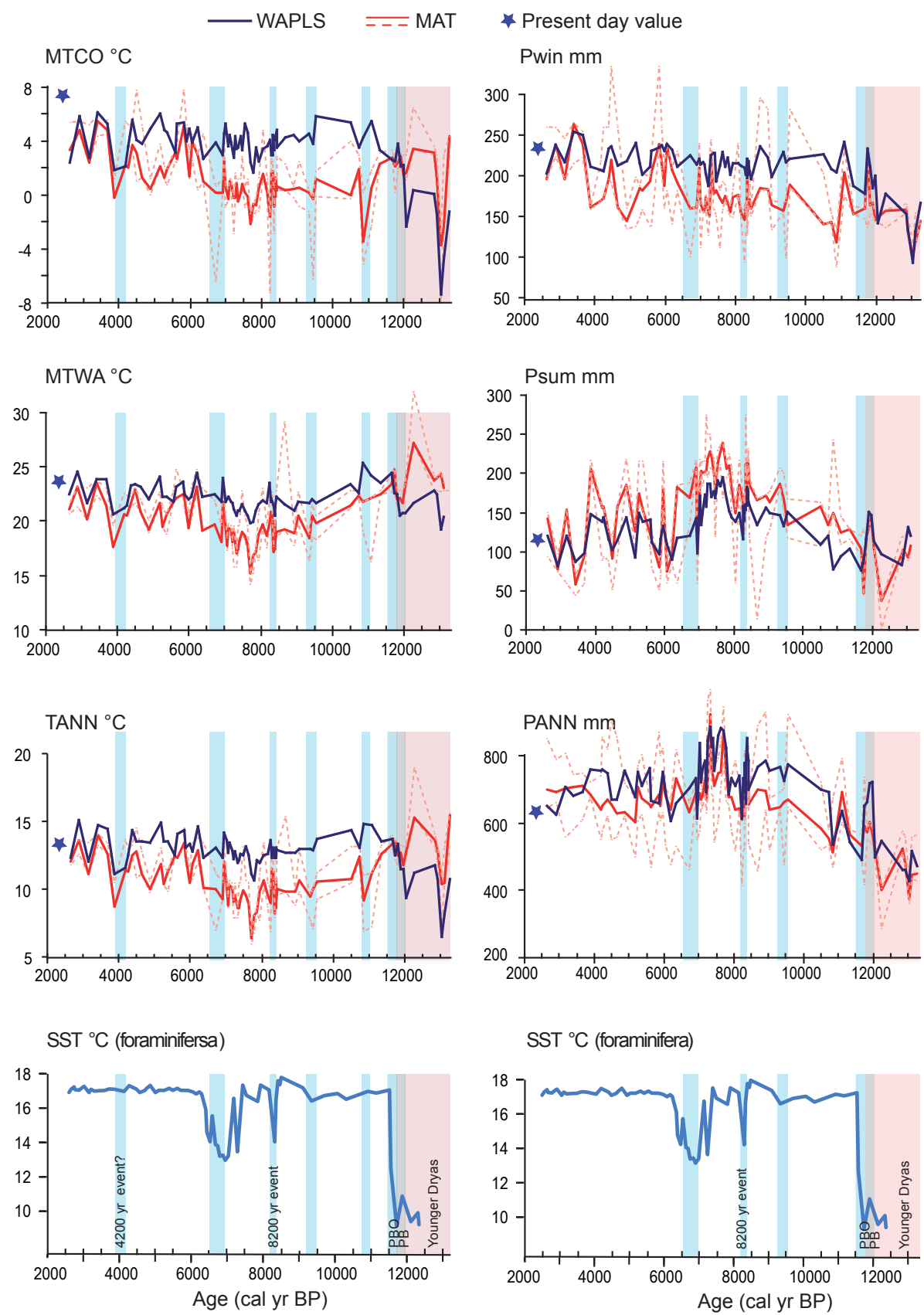

Fig. 3. Quantitative climate reconstructions from pollen analyses obtained by the MAT (red: dotted line corresponds to error) and WAPLS (blue) methods. Present-day values for temperature (MTCO, MTWA and TANN) and precipitation (Pwin, Psum and PANN) are represented by blue stars. SSTs (blue) from the same core are reported at the base of the figure for comparison with the pollen inferred reconstruction. All curves are presented in cal yr BP. Colored bars underline climate events: YD (pink), PB (grey), PBO and Holocene events (blue).

found in southern Greece on the Balkan Peninsula (Ozenda, 1975), thus Olea pollen grains are more likely to arrive from the Italian coast. Nevertheless, olive cultivation by human societies during the last millennia (Mercuri et al., 2013) may contribute to broader Olea representation. Picea today grows only in the Dalmatian mountains, in the northern Apennines and the Alps, therefore its pollen is likely to be derived from these areas, brought to the Adriatic core site by Po River inflow. Picea may also be carried by eastern winds, however, Picea pollen grains are considered to be transported relatively short distances by wind in Europe (Hicks, 2001), thus Picea pollen is probably of northern origin, deposited to the site by discharge from the Po River. 
Ultimately, pollen inputs into the Adriatic Basin will draw a broad regional picture of Italian and Balkan vegetation from the wide range of habitats extending from the coasts to the highlands.

\subsection{Clay mineral origin}

The Po River and the eastern Apennine rivers are the main sources of clay-sized particles in the western Adriatic. Although Apennine rivers have relatively small drainage areas, studies have shown that they have very high sediment contributions relative to their drainage area (Frignani et al., 1992; Milliman and Syvitski, 1992; Alvisi et al., 1996; Bartolini et al., 1996; Sorgente, 1999; Tomadin, 2000). Detrital material in the Po River comes largely from the Alps, supplying illite, associated with chlorite, to the Adriatic Sea (Chamley, 1989; Alonso and Maldonado, 1990; Tomadin, 2000). Because illite is resistant to degradation and transport it generally represents the relative contribution of physical weathering to sedimentation. As a result, illite dominates the clay mineral sediment fraction in the deeper parts of the Adriatic (Tomadin, 2000). By contrast, Apennine sediment sources are rich in smectite, which is mainly dispersed southeastward along the coast, with further downslope transport toward the deep basin through seasonal gradient and turbidity currents (Franco et al., 1982; Tomadin, 2000).

Croatian rivers to the east, containing illite and kaolinite with minor smectite components (Durn et al., 1999) and Albanian rivers to the south, carrying smectite, supply sediment to the eastern Adriatic. The contribution of these river inputs is reduced because of very low riverine terrigenous loads and particles trapped along the Adriatic margin (e.g. Tomadin, 2000; Cattaneo et al., 2003).

The eolian contribution to deep-sea sediments is of major importance in the Mediterranean. Massive desert dust plumes export clay-mineral particles toward the Mediterranean (Rea et al., 1985; Guerzoni and Chester, 1996) via regional meridian wind systems (Prospero, 1981; Loÿe-Pilot et al., 1986; Pye, 1987; Bergametti et al., 1989; Tomadin and Lenaz, 1989; Guerzoni and Chester, 1996; Guerzoni et al., 1999; Moulin et al., 1997; Rodriguez et al., 2001; Torres-Padrón et al., 2002; Ginoux et al., 2004). Illite and kaolinite can also be transported through eolian processes. Kaolinite abundance is highest in the southeastern Sahara compared to western Sahara, while illite displays the reverse pattern (Avila et al., 1997; Caquineau et al., 1998; Guerzoni et al., 1999). The southerly sirocco wind most likely supplies eolian kaoliniterich dusts from North Africa to the Adriatic Sea during spring and summer (Goudie and Middleton, 2001).

\section{Vegetation and climate for core MD 90-917}

Palynological investigations using marine sediment cores have confirmed close links between pollen data from marine sediments and regional vegetation, and the ability of marine palynology to reconstruct climate changes at a regional scale (e.g. Heusser and Balsam, 1977; Hooghiemstra et al., 1992, 2006; Combourieu-Nebout et al., 2009). The reconstructed vegetation history for MD90-917 is similar to other Italian and Balkan sequences for the Holocene, which suggests the pollen from MD 90-917 can reveal the consequences of the regional climatic change during the last $13000 \mathrm{cal}$ yr BP on central Mediterranean vegetation (Table 2, Fig. 2a, b)

The Younger Dryas event (GS-1 event - YD) is characterized by the dominance of semi-desert elements such as Artemisia, Chenopodiaceae and Ephedra (Fig. 2b) accompanied by Poaceae and Asteraceae, which developed extensively around a lowered Adriatic Sea (also described in Combourieu-Nebout et al., 1998). This steppic vegetation is recorded in numerous regional pollen records (e.g. Watts et al., 1996; Magri and Sadori, 1999; Denèfle et al., 2000; Allen et al., 2002; Bordon et al., 2009; Kotthoff et al., 2011; Combourieu-Nebout et al., 2009; Fletcher et al., 2010; Desprat et al., 2013). Steppic pollen taxa indicate that coldarid climate conditions prevailed over the whole Mediterranean Basin and especially in the Adriatic Basin during the Younger Dryas (Figs. 3, 4).

Between 12000 and 11700 cal yr BP, semi-desert elements are replaced by arboreal associations composed by Quercus, Carpinus, Corylus and Abies showing the afforestation driven by climatic warming at the beginning of the Holocene (Fig. 2a). Although it begins at an older age in the MD 90-917 marine core, such a spread of temperate taxa may be related to what is observed in several pollen sequences across the central Mediterranean (e.g. Watts et al., 1996; Sadori and Narcisi, 2001; Allen et al., 2002; Sadori et al., 2011; Di Rita et al., 2013) and corresponds to the Preboreal (PB) improvement at the Younger Dryas/Holocene transition (Björk et al., 1996). Forest expansion is interrupted by a strong drop in arboreal taxa around $11700 \mathrm{cal} \mathrm{yr} \mathrm{BP,} \mathrm{marked}$ by an increase in herbaceous taxa (Asteroideae and Cichoriodeae) and semi-desert taxa, excluding Artemisia (Fig. 2a, b). Climate reconstructions using pollen data show a decrease in temperature and precipitation at this time for the two methods (Figs. 3, 4). Although lake records from the central Mediterranean are rare, the same pattern can be seen, an increase in temperate forest followed by a slight return of herbs (e.g. Lake Trifoglietti - Joannin et al., 2012; Valle di Castiglione - Di Rita et al., 2013). Thus, the climate oscillation recorded in the MD90-917 appears to follow the pattern observed in the Greenland ice cores' $\delta^{18} \mathrm{O}$ record (Fig. 5; Rasmussen et al., 2007) and probably corresponds to the $\sim 11300 \mathrm{cal}$ yr BP Preboreal oscillation recorded in the Greenland ice cores (PBO: Björk et al., 2001; Magny et al., 2012).

In the early Holocene, the general trend of the vegetation data and pollen-based climate reconstructions precede the foraminifer-based SST (sea surface temperature) from the same core (Siani et al., 2013) (Figs. 3, 5) in the same pattern 


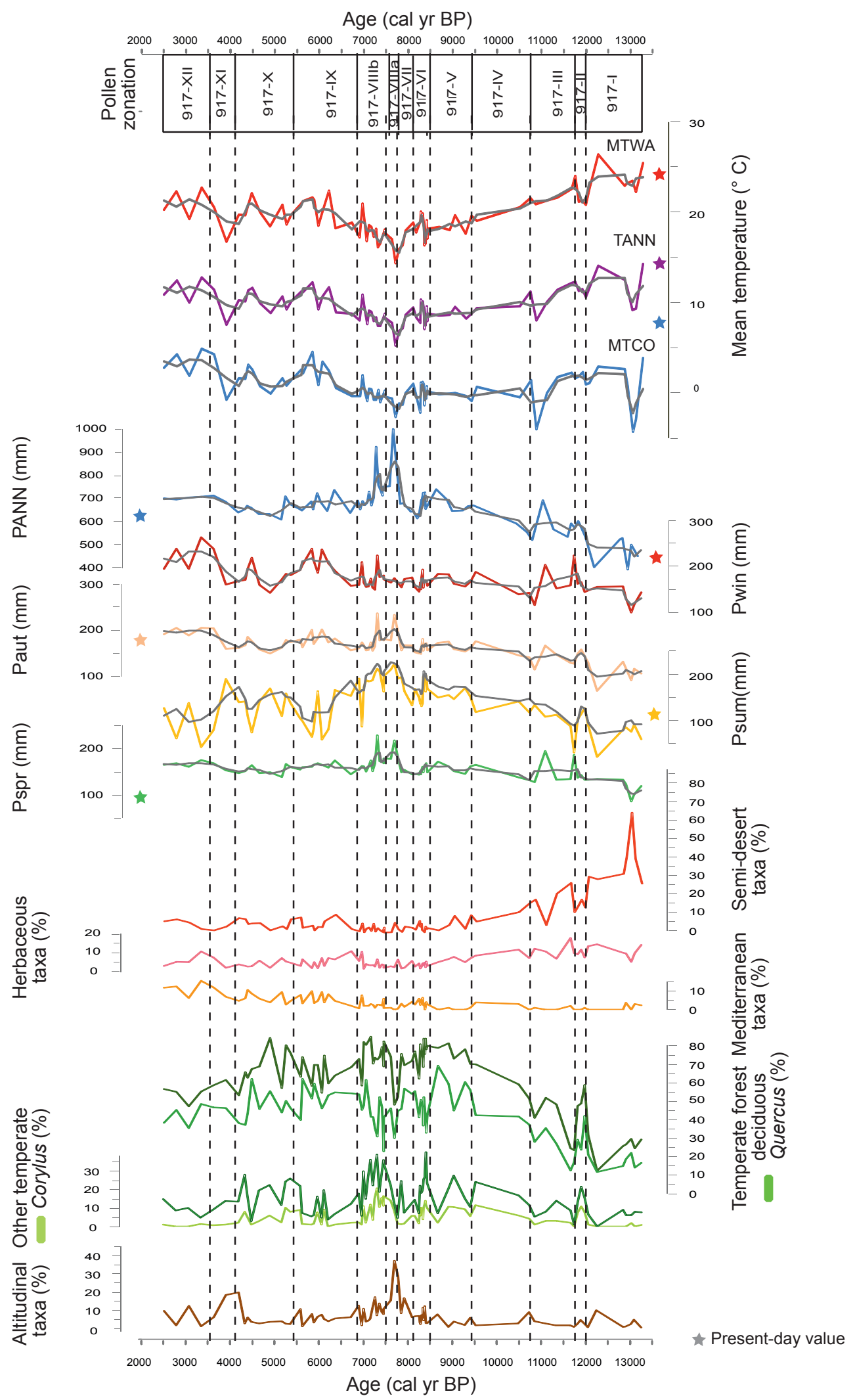

Fig. 4. Selected pollen curves of core MD 90-917 and pollen based reconstruction of precipitation (seasonal: Pspr, Psum, Paut, Pwin and annual: PANN) and temperature ( MTCO, MTWA and TANN). All curves are presented in cal yr BP. Grey curves are the 3 pts-smoothed curves. Colored stars represent the present-day values for each climate parameter. 


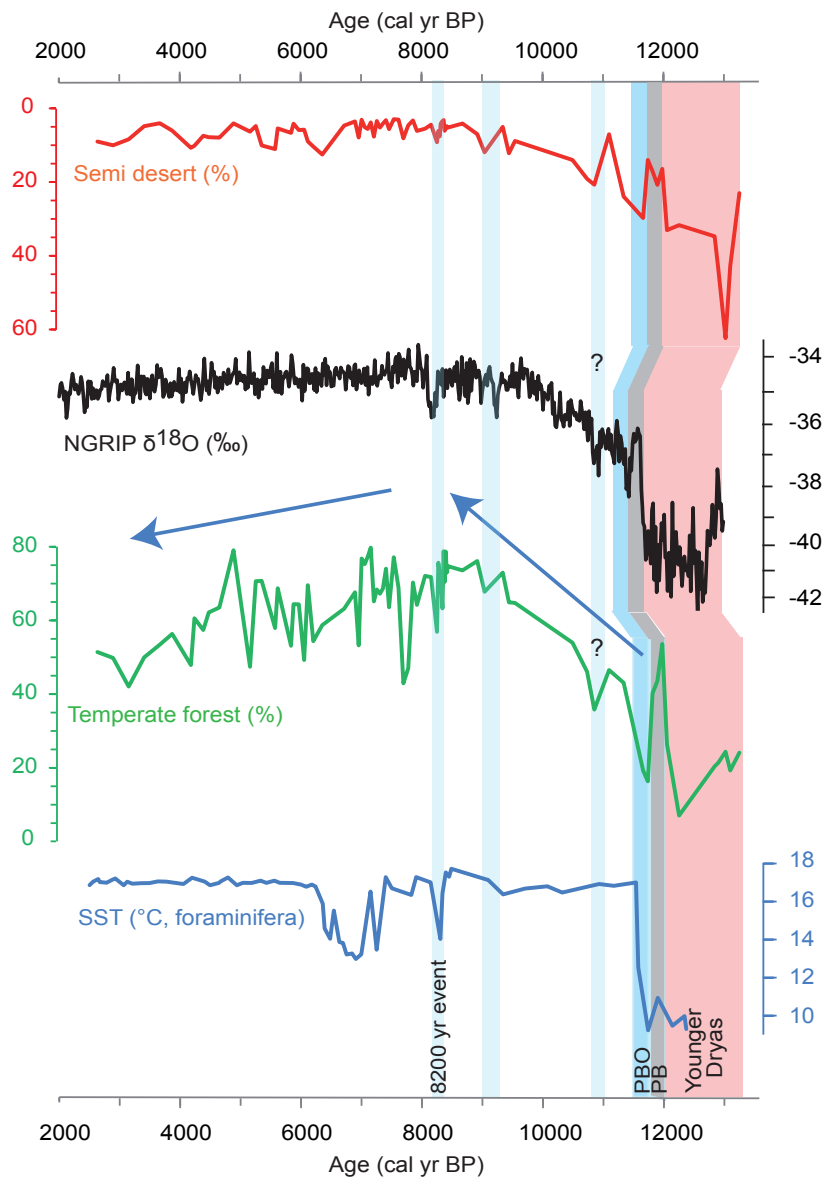

Fig. 5. Comparison between two main pollen groups (this paper); temperate trees (green), semi-desert (red) and SST (blue) from the core MD 90-917 and NGRIP oxygen isotope record (NGRIP members, 2004; Lemieux Dudon, 2011). Colored bars underline climate events: YD (pink), PB (grey), PBO and 8200 cal yr BP event (purple). Curves are plotted according to their respective age models in cal year BP. The time lag observed between MD 90-917 and NGRIP records during the YD-Holocene transition is probably due to ${ }^{14} \mathrm{C}$ age uncertainties displayed in the MD 90-917 age model. The question marks indicate potential events not sufficiently documented in the record.

as the alkenone-inferred SST response (Sicre et al., 2013). To explain such discrepancies, Sicre et al. (2013) suggest a local response in alkenone-inferred SST record. In fact, the temporal lead shown in MD 90-917 vegetation and pollen-based climate reconstruction records relative to foraminifer-based SST should not be related to local behavior as it would imply a time lag with other Italian records such as Lake Trifoglietti (Joannin et al., 2012) and Lake Vico (di Rita et al., 2013) records; which would be amazing. Of course, the MD 90917 record represents the regional vegetation changes of the central Mediterranean and thus integrates vegetation changes evidenced in these contemporary Italian records. Another explanation might be that the lead in vegetation response rela- tive to foraminifer inferred SST from the same core suggests that the vegetation response to the Preboreal oscillation in the region could be driven by precipitation changes rather than temperature variations, which is quite different to the classic feature of climate changes observed at the beginning of interglacials (temperature rise generally preceding precipitation increase). Thus, the discrepancy between the different proxies obtained in the core MD 90-917 can be related to the sampling resolutions, which are not strictly similar in this part of the core, and the delay of SST response compared to vegetation may be due to the lack of samples in the PB-PBO interval. Given this, age discrepancies between continental, ice records and the MD 90-917 marine core vegetation proxy may be due to ${ }^{14} \mathrm{C}$ age control uncertainties in this part of the core; and that the vegetation event at $11700 \mathrm{cal}$ yr in MD 90-917 may be related without doubt to the Preboreal event.

After 11000 cal yr BP, a mixed deciduous forest (mainly dominated by Quercus with regular occurrence of and accompanied by Corylus, Carpinus, Fagus, Alnus, Betula) expands (Fig. 2a, b). The mixed forest peaks around $7000 \mathrm{cal} \mathrm{yr}$ BP corresponding to the "Holocene climate optimum". Deciduous forest expansion occurs in Italy and in the Balkan Peninsula at the same time (e.g. Watts et al., 1996; Jahns and van der Bogaard, 1998; Denèfle et al., 2000; Allen et al., 2002). Evidence for a climate optimum at 7000 cal yr BP agrees well with $\delta^{18} \mathrm{O}$ from planktonic foraminifers (Fig. 6) and the foraminifer inferred SST increase from the MD 90917 core (Siani et al., 2013). Increases in regional forest biomass also concur with $\delta^{13} \mathrm{C}$ depletion in the MD 90-917 sediments, linked to sea-level rise (Siani et al., 2013) in the early-Holocene since depletion in $\delta^{13} \mathrm{C}$ in core sediments may also be interpreted as an intensification of nutrient supply from the continent to the Adriatic Sea.

Although temperate forest dominates the vegetation record from 11000 until 7000 cal yr BP there are several compositional shifts in that time (Figs. 2a, 4). Inferred vegetation is dominated by Quercus, which declines repeatedly. Quercus is sometimes replaced by a mixed deciduous forest with Corylus, Carpinus, and Fagus, occasionally associated with Fraxinus and Alnus, or is replaced by a mixed coniferous forest with Abies and Picea. In the first case, Quercus dominated forests are replaced with mixed deciduous forests at around 8300 and 7500 cal yr BP, possibly the expression of a forest opening, resulting in the expansion of heliophilous taxa, sporadically developing in the Quercus forest and/or on the forest edges. Such changes might be due to slight changes in summer temperature and precipitation (Fig. 3) or changes in the spring and autumn (Fig. 4). In the second case, Quercus forest is replaced by mixed coniferous forest at 7700 cal yr BP with Abies and Picea. This change might reflect a slight cooling and/or change in the seasonality of precipitation, particularly in the Balkan massifs and/or on the northern part of Adriatic Basin given that delivery of Picea pollen to the core occurs (i) from the rivers of the northern Adriatic slopes and/or (ii) from northern Italy and Alps by Po River 


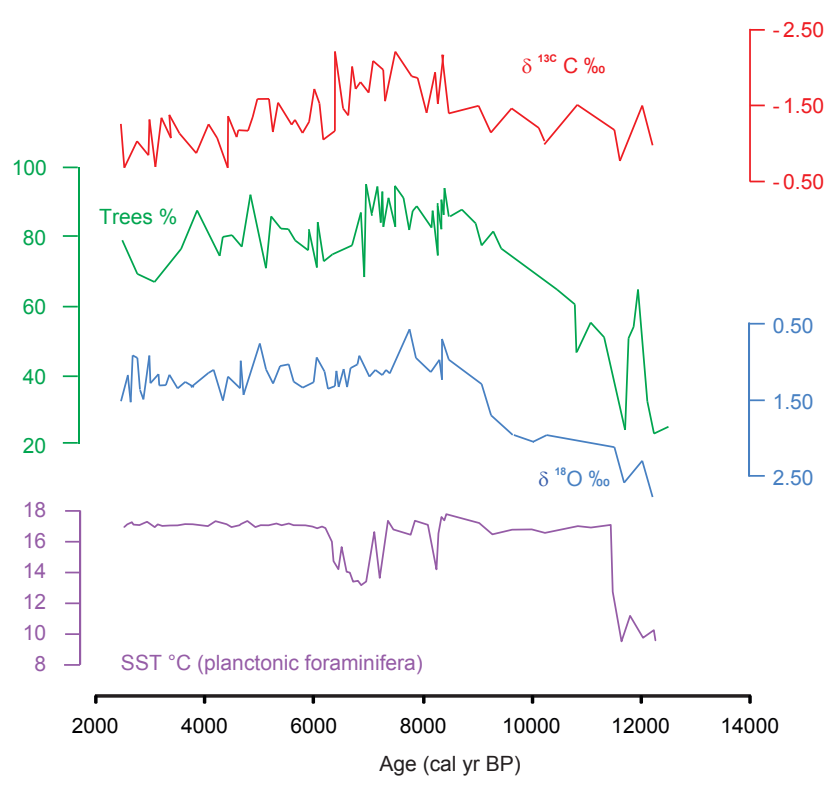

Fig. 6. Comparison of the total tree percentage curve (green) (this paper) and the $\delta^{18} \mathrm{O}$ (blue), $\delta^{13} \mathrm{C}$ (red) and SST $\left({ }^{\circ} \mathrm{C}\right.$, purple) records from the MD 90-917 core (Siani et al., 2013). All curves are presented in cal yr BP.

discharges and then by marine flows. Picea has not been observed in central and southern Italy during the Holocene, only occurring in the Po Valley, northern Italy and over the northern Balkans (Ravazzi et al., 2002; Van der Knaap et al., 2005). Abies and Picea pollen grains are not well-transported by wind (only at $5 \mathrm{~m}$ away from the trees) and rarely dominate airborne pollen assemblages (Hicks, 2001; Sjögren et al., 2008). As a result, the Abies and Picea increase at $\sim 7700$ cal yr BP could therefore express the development of mixed Abies and Picea forests in the north and northeast mountains around the Adriatic Basin, with the pollen being transported through river flows.

Temperate forest dominated by Quercus have fluctuated between 7000 and 5000 cal yr BP, decreasing after 4500 cal yr BP. Quercus became less abundant while Carpinus, Corylus and Alnus increased. This marks progressive opening of the forest, corresponding to decreases in summer precipitation, reflected in the pollen-based climate reconstructions based on the MAT and the WAPLS (Fig. 3). A cold, moist event is inferred from the rise in Abies, Fagus, and to a lesser extent Picea around 4000 cal yr BP (Fig. 4). Increased precipitation would have increased river flows, bringing the poorly dispersed Abies pollen to the core location. The upper samples of the core sequence, to $3000 \mathrm{cal}$ yr BP, show an increase in herbaceous taxa (Asteraceae and Poaceae), continuing the trend of declining tree cover, probably influenced by increasing of human impacts in coastal Italy and Balkan. The increase in steppic elements such as Artemisia during this period may also indicate regional drying, particularly in the summer, and may represent the establishment of the sum- mer conditions associated with the modern Mediterranean climate.

Mediterranean taxa, primarily $Q$. ilex, are continuously present in the pollen record beginning at $8000 \mathrm{cal} \mathrm{yr} \mathrm{BP}$. The Mediterranean forest begins to diversify after $6000 \mathrm{cal}$ yr BP with the continuous presence of Olea and Phillyrea pollen, and, after $3500 \mathrm{cal}$ yr BP with the presence of Pistacia. This coincides with the decreasing abundance of deciduous trees, especially deciduous Quercus and the increase in herbs such as Asteraceae and steppic taxa (Artemisia excluded) at $3500 \mathrm{cal}$ yr BP. This pattern has been observed elsewhere in the central Mediterranean (Sadori et al., 2011) and marks a shift in the precipitation regime, with decreasing summer precipitation and a progressive establishment of the modern Mediterranean climate (Figs. 3, 4). Olea, the emblematic plant of the Mediterranean area, occurs weakly at the beginning of the Holocene and remains sporadic up to $6000 \mathrm{cal}$ yr BP, generally associated only with warming climate. After $6000 \mathrm{cal}$ yr BP Olea is continuously present but is most abundant in the upper part of the record, around 3000 cal yr BP, in agreement with the central Mediterranean vegetation history proposed by Sadori et al. (2011) using continental records. Olea is present in marine records across the Mediterranean at this time (e.g. Combourieu-Nebout et al., 2009; Desprat et al., 2013) and may also reflect the development of olive cultivation at Italian sites (e.g. Lake Pergusa, Mercuri et al., 2013; Sadori et al., 2013) and possibly in the Balkans.

\section{Climate interpretation}

\subsection{Temperature pattern}

Temperature estimates from the MD 90-917 pollen sequence (Figs. 3, 4) are the first to be reconstructed from Adriatic marine sediments. These results can be compared to temperature signals reconstructed from terrestrial pollen sequences at lakes Ledro, Trifoglietti, Accesa and Pergusa (Fig. 1) for a direct land-sea comparison (Peyron et al., 2013). We present TANN, MTCO and MTWA temperature reconstructions from MD 90-917 provided by two methods: the MAT and the WAPLS (Fig. 3). The lowest MTCO in the record occurs before $12000 \mathrm{cal}$ yr BP, when temperatures are $5-7^{\circ} \mathrm{C}$ lower than preceding and subsequent periods. After these coldest values, MTCO increases towards higher values and then oscillate around $0{ }^{\circ} \mathrm{C}$ with a slight decreasing trend. The temperatures obtained with the WAPLS were lower during the YD than during the Holocene, which makes sense and suggests that the MAT may provide lower quality results during the Younger Dryas and Preboreal (Ortu et al., 2010a, b). However, Holocene results are consistent between methods. Temperatures (TANN and MTWA) minima are observed around $7700 \mathrm{cal} \mathrm{yr} \mathrm{BP}$, at which point they increase gradually through the upper part of the record (Fig. 3). 
Temperature anomalies reconstructed between $6000 \mathrm{cal} \mathrm{yr}$ $\mathrm{BP}$ and present-day are similar to those proposed for southern Italy by Wu et al. (2007), reinforcing the reliability of our climate reconstruction trends. The reconstructed temperature anomaly $\left(T^{\circ} \mathrm{C}\right.$ reconstructed $-T^{\circ} \mathrm{C}$ present-day) record from MD 90-917 also mirrors the southwestern European temperature curve reconstructed using more than 500 continental pollen records by Davis et al. (2003) (Fig. 7), who also indicate low temperature anomalies during the mid-Holocene. This confirms that the pollen record in the Adriatic reflects southwestern Mediterranean climate influences, more so than southeastern influences. The low anomalies likely reflect the strength of the north-south Mediterranean gradient (Magny et al., 2012) and an increase in the influence of westerlies in the northcentral Mediterranean during the late Holocene.

Temperature reconstructions indicate several cold and/or dry events during the last $13000 \mathrm{cal}$ yr BP: the Younger Dryas event, the Preboreal oscillation, the $8200 \mathrm{cal}$ yr BP event, and others events at 7700, 7000, 6400, 5000, 4200 and 3000 cal yr BP (Fig. 3). These cold events are associated with declines in Quercus pollen, and have been detected in other marine cores from the Mediterranean (Fig. 8; e.g. Combourieu-Nebout et al., 2009; Schmiedl et al., 2010; Fletcher et al., 2010, 2012; Desprat et al., 2013) and may be linked to the millennial-scale cold events recorded in the North Atlantic (Bond et al., 1997, 2001; Kotthoff et al., 2008a; Combourieu-Nebout et al., 2009; Schmiedl et al., 2010; Fletcher et al., 2010, 2012; Fletcher and Zielhofer, 2011; Desprat et al., 2013, Magny et al., 2013). The rapid response of the central Mediterranean to millennial-scale variability confirms the influence of midlatitude atmospheric circulation in propagating changes, depending on insolation and ice sheet volume (Desprat et al., 2013). Our reconstruction suggests that the first two events (Younger Dryas and Preboreal oscillation) were characterized by sharp seasonal contrast with respectively cold/cool winters and warm summer); this pattern differs strongly from the modern climate, which established itself progressively after $7700 \mathrm{cal}$ yr BP with warmer winters more favorable to Mediterranean forest communities (Fig. 3).

\subsection{Precipitation pattern}

Pollen-inferred annual precipitation for MD 90-917 shows an increasing trend from 12000 to $7000 \mathrm{cal} \mathrm{yr} \mathrm{BP}$ reaching highest values between 8000 and $7500 \mathrm{cal} \mathrm{yr} \mathrm{BP} \mathrm{(Figs.} \mathrm{3,}$ 4). This trend is mirrored by Pspr and Paut precipitation, but, while Psum and PANN precipitation show similar trends of increasing precipitation from the early Holocene to 7500 cal yr BP, summer precipitation declines more strongly than annual precipitation towards $3000 \mathrm{cal} \mathrm{yr}$ BP. The MAT and the WAPLS results show an unambiguous increase in summer precipitation during the mid-Holocene (Fig. 3) even if the MAT may slightly overestimate the summer precipitation and underestimate the winter precipitation (Combourieu-

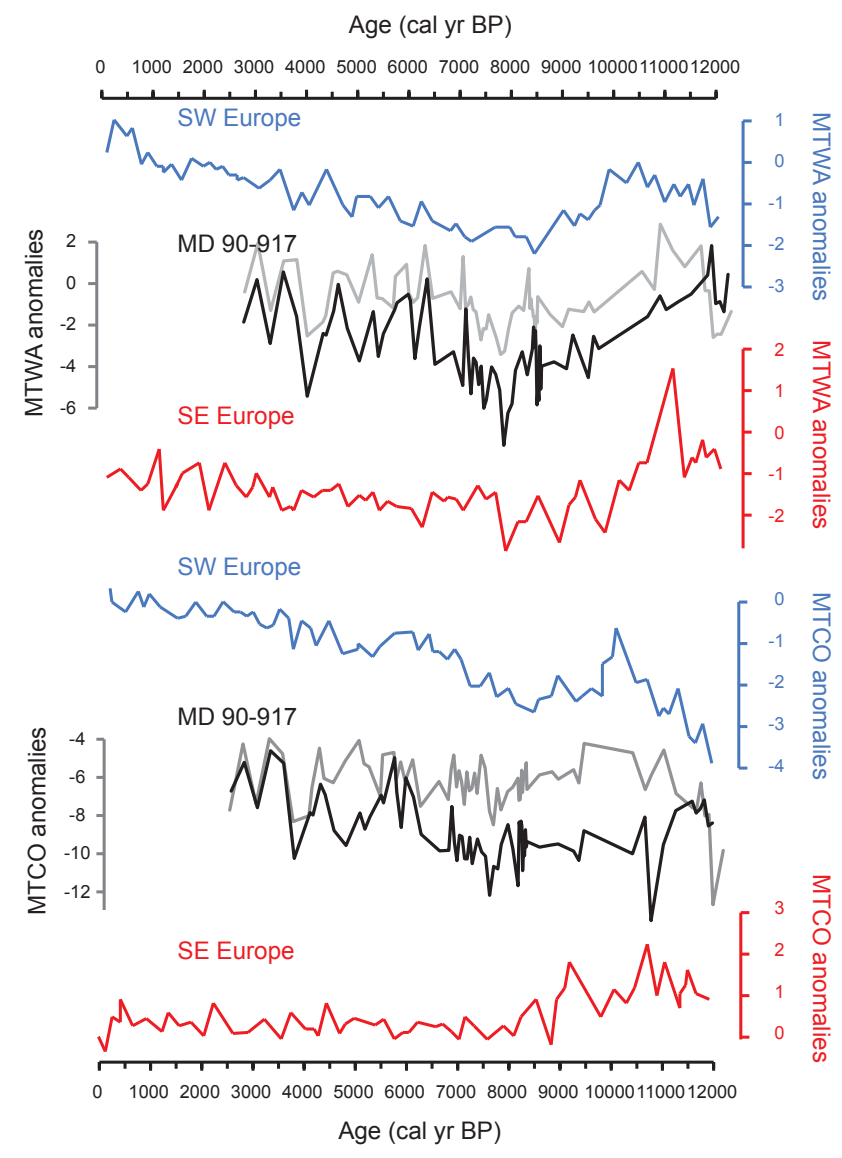

Fig. 7. Comparison between MD 90-917 pollen-based MTCO and MTWA temperature reconstructions (MAT in black, WAPLS in grey) and the combined climate records of southeastern and southwestern Europe (from Davis et al., 2003). Curves are presented in temperature anomalies (reconstructed values minus present-day values).

Nebout et al., 2009). The Holocene's summer precipitation trend inferred from our pollen data is similar to speleothem records in central Italy (Zhorniak et al., 2011) and the eastern Mediterranean (Bar-Matthews et al., 1998; Bar-Matthews and Ayalon, 2011), although speleothem-record features should be linked to changes in winter precipitation. However interpretations of speleothem records in terms of precipitation seasonality in the central and eastern Mediterranean remain a matter of debate (Zhorniak, 2011) (Fig. 9).

The summer precipitation record also matches the lakelevels pattern described by Magny et al. (2012), which suggests that lakes located southward of $40^{\circ} \mathrm{N}$ experienced high lake levels during precipitation maxima in the early to midHolocene in Italy while northern Italian lakes were characterized by low lake levels. The summer precipitation inferred from four Italian pollen records appears to confirm the opposing precipitation regimes for northern and southern sites in the Mediterranean during the Holocene (Peyron et al., 2013). There is strong agreement between the high lake 


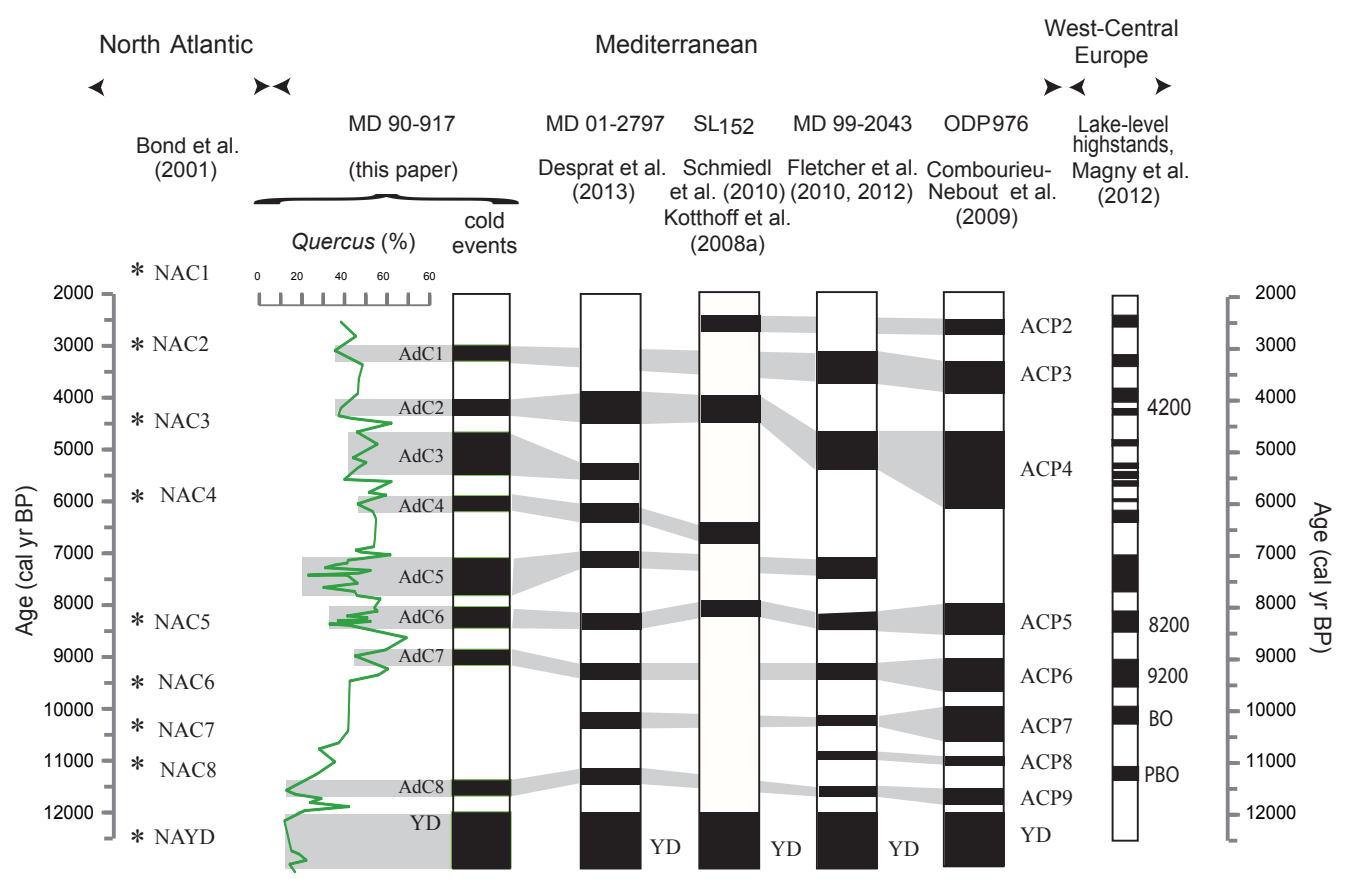

Fig. 8. Comparison of millennial cold events recorded in MD 90-917 with the cold events recorded from vegetation changes in other Mediterranean marine cores (Kotthoff et al., 2008a; Schmiedl et al, 2010; Fletcher et al., 2010, 2012; Combourieu-Nebout et al., 2009; Desprat et al., 2013). On the left are the North Atlantic Bond events (Bond et al., 2001) and, on the right, the periods of high lake levels recorded in the southern Alps (Magny et al., 2012).

levels reconstructed in Sicily, the wet summer conditions reconstructed for southern Italy by Peyron et al. (2013) and the summer precipitation inferred from the MD 90-917 pollen record. The MD 90-917 summer precipitation curve shows similarities to the northern Italy Lake Ledro record during the early Holocene while the mid-to-late Holocene precipitation curve fits with the southern Mediterranean summer precipitation trend (Fig. 8, Peyron et al., 2013). The MD 90917 precipitation pattern may support, at the mid-Holocene, a correlative increase in winter and summer precipitations with high summer precipitation and cooler temperatures at time of the boreal insolation maximum. Such a signal may illustrate the possible conflict of mid-latitudinal and subtropical monsoonal climatic systems in the Mediterranean area (Tzedakis, 2007; Revel et al., 2010; Desprat et al., 2013; Magny et al., 2013) and surely emphasizes the fact that our record is located at the confluence between northern and southern influences. Climate changes recorded here are clearly driven by insolation changes and likely reflect the increasing influence of westerlies during the second half of the Holocene, as demonstrated by the rise in winter precipitation in the upper part of our record.

Summer precipitation shows good fit to (i) sea surface salinity changes from the same core, interpreted as increasing runoff into the Adriatic deep sea basin (Siani et al., 2013) and (ii) changes in clay mineral composition (Fig. 9). Clay mineral records, presented as illite/kaolinite (I/K) and smec- tite/kaolinite (S/K) ratios (Fig. 9) reflect contributions from the eastern Apennine/Po Rivers and dust input from Africa respectively. These ratios clearly show a change in detrital input during the late-glacial and Holocene. Wind-blown dust (high kaolinite), supplied from the south by sirocco winds, is more abundant during the first part of the Holocene, while the rise of smectite after $9000 \mathrm{cal}$ yr BP indicates the increasing contribution from Italian rivers to the basin.

Both $\mathrm{I} / \mathrm{K}$ and S/K display a major peak at $12500 \mathrm{cal} \mathrm{yr}$ BP (Fig. 9), associated with an early rise in summer precipitation, suggesting important discharges from both the Po and the eastern Apennine rivers. A single S/K peak at 12000 cal yr BP suggests a major discharge from eastern Apennine rivers that is synchronous with the precipitation maxima, likely related to the Preboreal event.

Annual precipitation inferred from pollen data shows two maxima in the middle Holocene. During these two events, precipitation seasonality and temperature display two different patterns: (i) at $7700 \mathrm{cal} \mathrm{yr}$ BP, a longer humid season is combined with low summer and winter temperatures and (ii) at $7000 \mathrm{cal}$ yr BP precipitation is equitable with no noticeable change in temperature. These two peaks occur at the same time that clay mineral composition changes, with two different signatures, indicative of two distinct sources. The $7700 \mathrm{cal}$ yr BP event shows a major increase in the illite/kaolinite ratio, indicating major discharges from the Po River. This pattern of increasing inflow from the Po River 


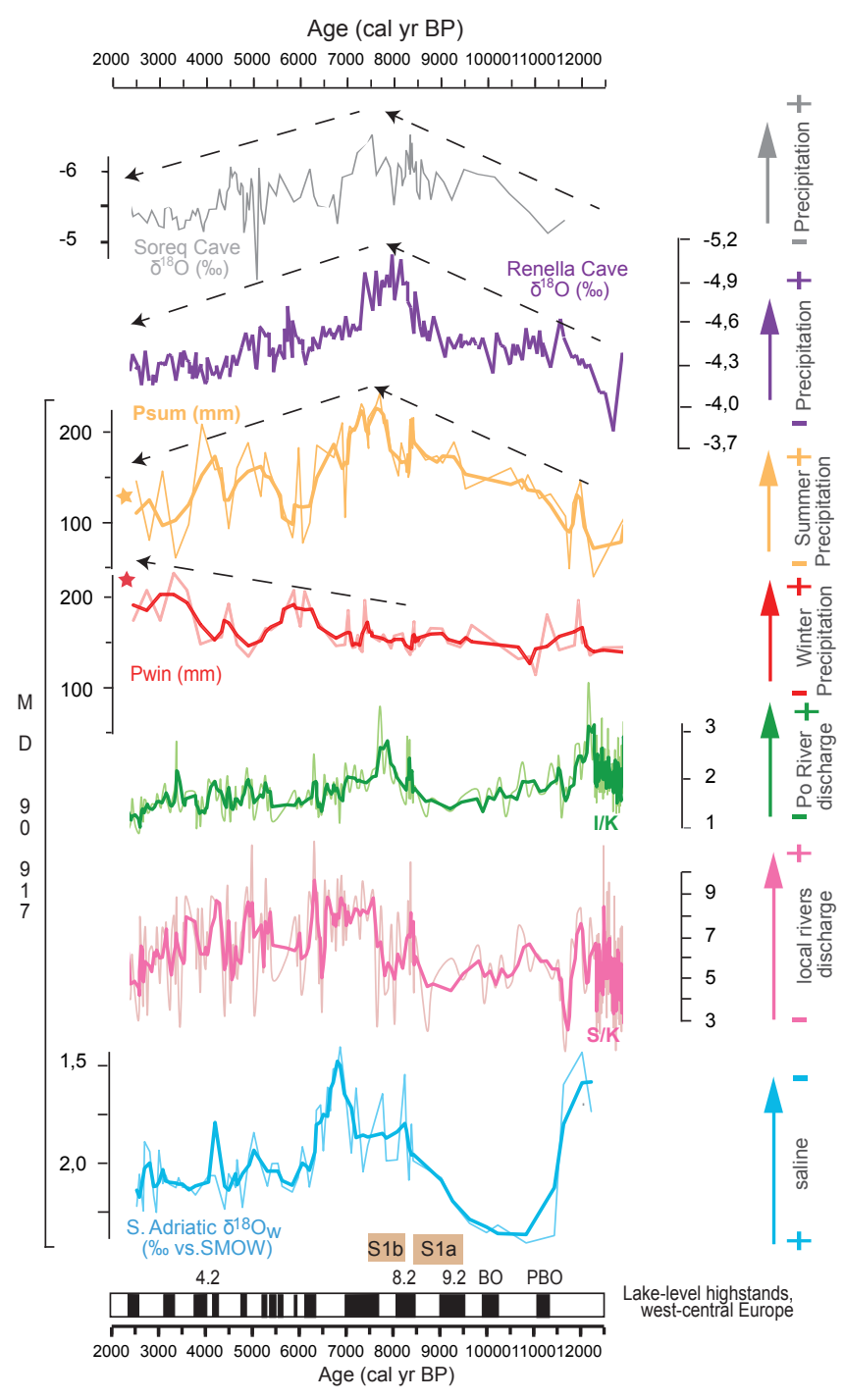

Fig. 9. Comparison of the Psum (yellow) and Pwin (red) precipitation changes reconstructed from MD 90-917 pollen data (MAT) and from bottom to top: lake level highstands in western Europe (Magny et al., 2012 column); sea surface salinity reconstructed from MD 90-917 $\delta^{18} \mathrm{O}$ record (Siani et al., 2013; blue), I/K (pink) and S/K (green) ratios from MD 90-917 and $\delta^{18} \mathrm{O}$ speleothem records from the Renella cave (Italy) (Zhornyak et al., 2011; purple) and Soreq cave (Israel) (Bar-Matthews et al., 1998; Bar-Matthews and Ayalon, 2011; grey). For MD 90-917 records, thin, light curves represent the original data and accentuated curves are the 3 pts-smoothed curves.

agrees well with increases in Picea and Abies pollen in the sediments and confirms the role of Po River discharge in the pollen signal, as well as its probable influence on declines in sea surface salinity during this event (Fig. 9). Both the origin and discharge rate of terrigenous inputs in the Adriatic Sea are seasonally modulated by precipitation distribution (Wheatcroft et al., 2001; Poulain, 2001). Modern seasonal precipitation influences discharge from the northern Adriatic, as is shown for recent floods in the Po River basin (Zanchet- tin et al., 2008). Therefore, increases in precipitation seasonality probably occurred during the $7700 \mathrm{cal}$ yr BP event, particularly in the northern and eastern Adriatic, leading to enhanced Po River discharges that would have driven salinity changes in the Adriatic Sea surface and transported Picea pollen toward the core's site. Such a process should explain why vegetation change from 8200 to $7500 \mathrm{cal} \mathrm{yr}$ BP reported from Trifoglietti (Joannin et al., 2012) is ascribed to a dry and cold phase. This dry phase does not appear in MD 90917, which shows changes similar to those observed in other Mediterranean records (e.g. Sadori and Narcisi, 2001; Allen et al., 2002).

The second climatic event, around $7000 \mathrm{cal} \mathrm{yr} \mathrm{BP,} \mathrm{shows}$ increasing annual precipitation without increasing Picea. At this time, sea surface waters are less saline based on $\delta^{18} \mathrm{O}$ from MD 90-917 (Siani et al., 2013). The $7000 \mathrm{cal}$ yr BP event occurs after the main peak of the illite/kaolinite ratio, indicating a reduced role for Po River discharges, but the event is synchronous with an increase in the smectite/kaolinite ratio. Sedimentological studies suggest that the respective contribution of the Po River and eastern Apennine rivers has varied through time (Cattaneo et al., 2003). Smectite is not presently supplied to the Adriatic through the Po River, originating from Italy's slopes through the small but active eastern Apennine rivers (Fig. 7). Based on the depth at which the core was obtained, sedimentation should be mostly under the influence of the illite-rich Po River plume, which flows southeastward in the open sea. The smectite-rich southeastward Apennine plumes are generally restricted to shallower depths along the coast. Smectite is transferred toward the deep basin through turbidity and gravity currents when river discharge increases seasonally (Tomadin, 2000). As a consequence the $7000 \mathrm{cal}$ yr BP event likely reflects a local pattern of change, reflecting increases in precipitation affecting the central Italian coast, nearest the core's site. This suggests that decreases in salinity were caused by inflow from local rivers. These inputs persisted throughout the second half of Holocene but it is likely that they were then too weak to induce any significant decrease in sea surface salinity in the Adriatic Sea.

\section{Conclusions}

The MD 90-917 marine pollen record illustrates the regional response of central Mediterranean vegetation to long-term and millennial climate fluctuations during the late-glacial and Holocene, and gives an integrated signal of temperature and precipitation changes during that period.

The early Holocene is clearly expressed in vegetation changes and, despite a short chronological time-lag with the ice core chronology, the Preboreal climate oscillation is recorded in the core by an expansion of central Mediterranean forest taxa, followed by the return of open vegetation. Shifts in vegetation during the Preboreal 
oscillation are probably driven by precipitation changes, especially summer precipitation, and are correlated with inputs from local and regional rivers since vegetation changes occurred prior to SST increases recorded in the MD 90-917 core.

Pollen-based temperature reconstructions follow patterns reconstructed using other proxies in the southern Mediterranean, with an increasing west and northwest climatic influence. Several cold events are recorded and may be linked to millennial-scale variability during the Holocene.

Precipitation reconstructed from the pollen record shows a trend of increasing annual and seasonal (winter) precipitation during the Holocene. Summer precipitation reflects a trend seen elsewhere in the southern Mediterranean, with maximum values (around $180-200 \mathrm{~mm}$ from the two methods) around $7000 \mathrm{cal} \mathrm{yr} \mathrm{BP}$ and then declining until $3000 \mathrm{cal}$ yr BP towards nearly present-day values $(<100 \mathrm{~mm})$. Two significant peaks in precipitation occur at $7700 \mathrm{cal} \mathrm{yr} \mathrm{BP}$ and between 7500 and $7000 \mathrm{cal} \mathrm{yr} \mathrm{BP}$ that are associated with peak runoff from the Po River and from local central Adriatic rivers respectively.

Acknowledgements. This study is a part of the LAMA ANR projects (MSHE Ledoux, USR 3124, CNRS) financially supported by the French CNRS (National Centre for Scientific Research). The authors received funding from French CNRS and CEA for their research. S. Goring is funded through the NSF-Macrosystems program, grant \#EF1065656. This research has been supported by the Institut Paul Emile Victor for the Prometée cruise of the R/V Marion Dufresne. Palynological samples were processed by J. P. Cazet and I. Dormoy. This is LSCE contribution no. 4587.

Edited by: M.-F. Loutre

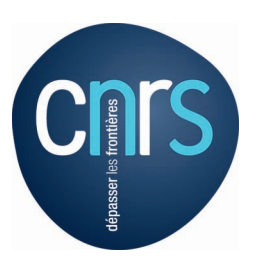

The publication of this article is financed by CNRS-INSU.

\section{References}

Allen, J. R. M., Watts, W. A., McGee, E., and Huntley, B.: Holocene environmental variability-the record from Lago Grande di Monticchio, Italy, Quatern. Int., 88, 69-80, 2002.

Alonso, B., and Maldonado, A.: Late Quaternary sedimentation patterns of the Ebro turbidite systems (northwestern Mediterranean): Two styles of deep-sea deposition, Mar. Geol., 95, 353377, 1990.

Alvisi, F., Beks, J., Frignani, M., Langone, L., Moodley, L., Mowbray, S., Price, N. B., and Ravaioli, M. : Toward a sediment and heavy metal mass balance for the western Adriatic Sea, 2nd Workshop MYP-MAST, Iraklio, Greece, extended abstracts, 5964, 1996.
Avila, A., Queralt-Mitjans, I., and Alarcón, M. : Mineralogical composition of African dust delivered by red rains over northeastern Spain, J. Geophys. Res., 102, 21977-21996, 1997.

Bar-Matthews, M. and Ayalon, A.: Mid-Holocene climate variations revealed by high-resolution speleothem records from Soreq Cave, Israel and their correlations with cultural changes, Holocene, 21, 163-172, 2011.

Bar-Matthews, M., Ayalon, A., and Kaufman, A.: Middle to late Holocene (6500 yr period) paleoclimate in the Eastern Mediterranean region from stable isotopic composition of speleothems from Soreq Cave, Israel, in: Environment and society in times of climate change, edited by: Issar, A. and Brown, N., Kluwer Academic, Dordrecht, 203-214, 1998.

Bartolini, C., Caputo, R., and Pieri, M.: Pliocene-Quaternary sedimentation in the Northern Apennines Foredeep and related denudation, Geol. Mag., 133, 255-273, 1996.

Bergametti, G., Gomes, L., Remoudaki, E., Desbois, M., Martin, D., and Buat-Menard, P.: Present transport and deposition patterns of African dusts to the North-Western Mediterranean, in: Paleoclimatology and Paleometeorology: Modern and past patterns of global atmospheric transport, edited by: Leinen, M. and Sarnthein, M., Dordrecht, Kluwer Academic, 282, 227-251, 1989.

Björck, S., Kromer, B., Johnsen, S., Bennike, O., Hammarlund, D., Lemdahl, G., Possnert, G., Rasmussen, T.L., Wohlfarth, B., Hammer, C. U., and Spurk, M.: Synchronized terrestrialatmospheric deglacial records around the North Atlantic, Science, 274, 1155-1160, 1996.

Björck, S., Muscheler, R., Kromer, B., Andresen, C. S., Heinemeier, J., Johnsen, S. J., Conley, D., Koç, N., Spurk, M., and Veski, S.: High-resolution analyses of an early Holocene climate event may imply decreased solar forcing as an important climate trigger, Geology, 29, 1107-1110, 2001.

Bond, G., Showers, W., Cheseby, M., Lotti, R., Almasi, P., deMenocal, P., Priore, P., Cullen, H., Hajdas, I., and Bonani, G.: A pervasive millennial-scale cycle in North Atlantic Holocene and Glacial Climates, Science, 278, 1257-1266, 1997.

Bond, G., Kromer, B., Beer, J., Muscheler, R., Evans, M. N., Showers, W., Hoffman, S., Lotti-Bond, R., Hajdas, I., and Bonani, G.: Persistent solar influence on North Atlantic climate during the Holocene, Science, 294, 2130-2136, 2001.

Bordon, A., Peyron, O., Lézine, A., Brewer, S., and Fouache, E.: Pollen-inferred Late-Glacial and Holocene climate in southern Balkan (Lake Maliq), Quatern. Int., 200, 19-30, 2009.

Bout-Roumazeilles, V., Nebout, N. C., Peyron, O., Cortijo, E., Landais, A., and Masson-Delmotte, V.: Connection between South Mediterranean climate and North African atmospheric circulation during the last 50,000 yr BP North Atlantic cold events, Quaternary Sci. Rev., 26, 3197-3215, 2007.

Caquineau, S., Gaudichet, A., Gomes, L., Magonthier, M.-C., and Chatenet, B.: Saharan dust: clay ratio as a relevant tracer to assess the origin of soil-derived aerosols, Geophys. Res. Lett., 25, 983986, 1998.

Cattaneo, A., Correggiari, A., Langone, L., and Trincardi, F.: The late-Holocene Gargano subaqueous delta, Adriatic shelf: Sediment pathways and supply fluctuations, Mar. Geol., 193, 61-91, 2003.

Chamley, H.: Clay sedimentology, Berlin, Springer-Verlag, 623 pp., 1989. 
Combourieu-Nebout, N., Paterne, M., Turon, J.-L., and Siani, G.: A high-resolution record of the Last Deglaciation in the Central Mediterranean sea: palaeovegetation and palaeohydrological evolution, Quaternary Sci. Rev., 17, 303-332, 1998.

Combourieu-Nebout, N., Peyron, O., Dormoy, I., Desprat, S., Beaudouin, C., Kotthoff, U., and Marret, F.: Rapid climatic variability in the west Mediterranean during the last 25000 years from high resolution pollen data, Clim. Past, 5, 503-521, doi:10.5194/cp5-503-2009, 2009.

Davis, B. A. S., Brewer, S., Stevenson, A. C., Guiot, J., and data contributor: The temperature of Europe during the Holocene reconstructed from pollen data, Quaternary Sci. Rev., 22, 17011716, 2003.

Denèfle, M., Lezine, A. M. M., Fouache, E., and Dufaure, J. J.: A 12,000-year pollen record from Lake Maliq, Albania, Quaternary Res., 54, 423-432, 2000.

Desprat, S., Combourieu-Nebout, N., Essallami, L., Sicre, M. A., Dormoy, I., Peyron, O., Siani, G., Bout Roumazeilles, V., and Turon, J. L.: Deglacial and Holocene vegetation and climatic changes in the southern Central Mediterranean from a direct land-sea correlation, Clim. Past, 9, 767-787, doi:10.5194/cp-9767-2013, 2013.

Di Donato, V., Esposito, P., Russo-Ermolli, E., Scarano, A., and Cheddadi, R.: Coupled atmospheric and marine palaeoclimatic reconstruction for the last $35 \mathrm{ka}$ in the Sele Plain-Gulf of Salerno area (southern Italy), Quaternary Int., 190, 146-157, 2008

Di Rita, F. and Magri, D., Holocene drought, deforestation and evergreen vegetation development in the Central Mediterranean: a 5500 years record from Lago Alimini Piccolo, Apulia, Southeast Italy, Holocene, 19, 295-306, 2009.

Di Rita, F., Anzidei, A. P., and Magri, D.: A Late glacial and early Holocene pollen record from Valle di Castiglione (Rome): Vegetation dynamics and climate implications, Quaternary Int., 288, 73-80, 2013.

Dormoy, I., Peyron, O., Combourieu-Nebout, N., Goring, S., Kotthoff, U., Magny, M., and Pross, J.: Terrestrial climate variability and seasonality changes in the Mediterranean region between 15000 and 4000 years BP deduced from marine pollen records, Clim. Past, 5, 615-632, doi:10.5194/cp-5-615-2009, 2009.

Drescher-Schneider, R., de Beaulieu, J.-L., Magny, M., WalterSimonet, A.-V., Bossuet, G., Millet, L., Brugiapaglia, E. L., and Drescher, A.: Vegetation history, climate and human impact over the last 15000 years at Lago dell'Accesa (Tuscany, Central Italy), Veg. Hist. Archaeobot., 16, 279-299, 2007.

Dupont, L. M. and Wyputta, U.: Reconstructing pathways of aeolian pollen transport to the marine sediments along the coastline of SW Africa. Quatern. Sci. Rev., 22, 157-174, doi:10.1016/S02773791(02)00032-X, 2003.

Durn, G., Ottner, F., and Slovenec, D.: Mineralogical and geochemical indicators of the polygenetic nature of terra rossa in Istria, Croatia, Geoderma, 91, 125-150, 1999.

Faegri, K. and Iversen, J.: Textbook of Pollen Analysis, Munksgaard, Copenhagen. Denmark, 237 pp., 1964.

Finné, M., Holmgren, K., Sundqvist, H. S., Weiberg, E., and Lindblom, M.: Climate in the eastern Mediterranean, and adjacent regions, during the past 6000 years - A review, J. Archaeol. Sci., 38, 3153-3173, doi:10.1016/j.jas.2011.05.007, 2011.

Fletcher, W. J. and Zielhofer, C.: Fragility of Western Mediterranean landscapes during, Holocene Rapid Climate Changes, Catena,
103, 16-29, 2011.

Fletcher, W. J., Sanchez Goñi, M. F., Peyron, O., and Dormoy, I.: Abrupt climate changes of the last deglaciation detected in a Western Mediterranean forest record, Clim. Past, 6, 245-264, doi:10.5194/cp-6-245-2010, 2010.

Fletcher, W. J., Debret, M., and Sanchez Goñi, M. F.: Mid-Holocene emergence of a low-frequency millennial oscillation in western Mediterranean climate: implications for past dynamics of the North Atlantic atmospheric westerlies, The Holocene, 23, 153166, doi:10.1177/0959683612460783, 2012.

Franco, P., Jeftic, L., Malanotte Rizzoli, P., Michelato, A., and Orlic, M.: Descriptive model of the northern Adriatic, Oceanologica Acta, 5, 379-389, 1982.

Frignani, M., Langone, L., Pacelli, M., and Ravaioli, M.: Input, distribution and accumulation of dolomite in sediments of the Middle Adriatic Sea, Rapp. Comm. Int. Mer Medi., 33, p. 324, 1992.

Frignani, M., Langone, 1., Ravaioli, M., Sorgente, D., Alvisi, F., and Albertazzi, S.: Fine-sediment mass balance in the western Adriatic continental shelf over a century time scale, Mar. Geol., 222223, 113-133, 2005.

Ginoux, P., Prospero, J. M., Torres, O., and Chin, M.: Long-term simulation of global dust distribution with the GOCART model: correlation with North Atlantic Oscillation, Environ. Modell. Softw., 19, 113-128, 2004.

Giorgi, F.: Climate change hot-spots, Geophys. Res. Lett., 33, L08707, doi:10.1029/2006GL025734, 2006.

Giorgi, F. and Lionello, P.: Climate change projections for the Mediterranean region, Global Planet. Change, 63, 90-104, 2008.

Goudie, A. S. and Middleton, N. J.: Saharan dust storms: nature and consequences, Earth Sci. Rev., 56, 179-204, 2001.

Grimm, E. C.: "CONISS: a FORTRAN 77 program for stratigraphically constrained cluster analysis by the method of incremental sum of squares", Comput. Geosci., 13, 13-35, 1987.

Guerzoni, S. and Chester, R.: The Impact of Desert Dust Across the Mediterranean, Kluwer Academic, Dordrecht, 1996.

Guerzoni, S., Chester, R., Dulac, F., Herut, B., Loÿe-Pilot, M.-D., Measures, C., Migon, C., Molinaroli, E., Moulin, C., Rossini, P., Saydam, C., Soudine, A., and Ziveri, P.: The role of atmospheric deposition in the biogeochemistry of the Mediterranean Sea, Prog. Oceanogr., 44, 147-190, 1999.

Guiot, J.: Methodology of the last climatic cycle reconstruction in France from pollen data, Palaeogeogr. Palaeocl., Palaeoecol., 80, 49-69, 1990.

Heusser, L. E. and Balsam, W. L.: Pollen distribution in the NE Pacific ocean, Quaternary Res., 7, 45-62, 1977.

Hicks, S.: The use of annual arboreal pollen deposition values for delimiting tree-lines in the landscape and exploring models of pollen dispersal Rev Paleobotany and Palynology, 117, Special Issue: SI, 1-29, doi:10.1016/S0034-6667(01)00074-4, 2001.

Hooghiemstra, H., Stalling, H., Agwu, C. O. C., and Dupont, L. M.: Vegetational and climatic changes at the northern fringe of the Sahara 250000-5000 years BP: evidence from 4 marine pollen records located between Portugal and the Canary Islands, Rev. Palaeobot. Palynol., 74, 1-53, 1992.

Hooghiemstra, H., Leìzine, A.-M., Leroy, S. A. G., Dupont, L., and Marret, F.: Late Quaternary palynology in marine sediments: a synthesis of the understanding of pollen distribution patterns in the NW African setting, Quaternary Int., 148, 29-44, 2006. 
Horvat, I., Glavac, V., and Ellenberg, H.: Vegetation Südosteuropas, Geobotanica Selecta, 4, Stuttgart, 1974.

Hutson, W.: The Agulhas current during the Late Pleistocene: analysis of modern faunal analogs, Science, 207, 64-66, 1980.

IPCC: Climate Change 2007: Synthesis Report. Contribution of Working Groups I, II and III to the Fourth Assessment Report of the Intergovernmental Panel on Climate Change, Geneva, Switzerland, 104 pp., 2007.

Jahns, S. and van der Bogaard, C.: New palynological and tephrostratigraphical investigations of two salt lagoons on the island of Mljet, south Dalmatia, Croatia, Veget. Hist. Archaeobot., 7, 219234, 1998.

Jalut, G., Esteban Amat, A., Bonnet, L., Gauquelin, T., and Fontugne, M.: Holocene climatic changes in the Western Mediterranean, from south-east France to south-east Spain, Palaeogeogr. Palaeocl., Palaeoecol., 160, 255-290, 2000.

Jalut, G., Dedoubat, J. J., Fontugne, M., and Otto, T.: Holocene circum-Mediterranean vegetation changes: Climate forcing and human impact, Quaternary Int., 200, 4-18, doi:10.1016/j.quaint.2008.03.012, 2009.

Joannin, S., Brugiapaglia, E., de Beaulieu, J. L., Bernado, L., Magny, M., Peyron, O., Goring, S., and Vannière, B.: Pollenbased reconstruction of Holocene vegetation and climate in southern Italy: the case of Lago di Trifoglietti, Clim. Past, 8, 1973-1996, 2012,

http://www.clim-past.net/8/1973/2012/.

Joannin, S., Vannière, B., Galop, D., Peyron, O., Haas, J. N., Gilli, A., Chapron, E., Wirth, S., Anselmetti, F., Desmet, M., and Magny, M.: Climate and vegetation changes during the Lateglacial and Early-Mid Holocene in Lake Ledro (southern Alps, Italy), Clim. Past., 9, 913-933, doi:10.5194/cp-9-9132013, 2013.

Kotthoff, U., Muller, U. C., Pross, J., Schmiedl, G., Lawson, I. T., Van De Schootbrugge, B., and Schulz, H.: Lateglacial and Holocene vegetation dynamics in the Aegean region: An integrated view based on pollen data from marine and terrestrial archives, Holocene, 18, 1019-1032, 2008a

Kotthoff, U., Pross, J., Müller, U. C., Peyron, O., Schmiedl, G., and Schulz, H.: Climate dynamics in the borderlands of the Aegean Sea during formation of Sapropel S1 deduced from a marine pollen record, Quaternary Sci. Rev., 27, 832-845, 2008b.

Kotthoff, U., Koutsodendris, A., Pross, J., Schmiedl, G., Bornemann, A., Kaul, C., Marino, G., Peyron, O., and Schiebel, R.: Impact of late glacial cold events on the Northern Aegean region reconstructed from marine and terrestrial proxy data, J. Quaternary Sci., 26, 86-96, 2011.

Loÿe-Pilot, M.-D., Martin, J.-M., and Morelli, J.: Influence of Saharan dust on the rainfall acidity and atmospheric input to the Mediterranean, Nature, 321, 427-428, 1986.

Magny, M., Peyron, O., Sadori, L., Ortu, E., Zanchetta, G., Vannière, B., and Tinner, W.: Contrasting patterns of precipitation seasonality during the Holocene in the south- and northcentral Mediterranean, J. Quaternary Sci., 27, 290-296, 2012.

Magny, M., Combourieu Nebout, N., de Beaulieu, J. L., BoutRoumazeilles, V., Colombaroli, D., Desprat, S., Francke, A., Joannin, S., Peyron, O., Revel, M., Sadori, L., Siani, G., Sicre, M. A., Samartin, S., Simonneau, A., Tinner, W., Vannière, B., Wagner, B., Zanchetta, G., Anselmetti, F., Brugiapaglia, E., Chapron, E., Debret, M., Desmet, M., Didier, J., Essallami, L., Galop, D.,
Gilli, A., Haas, J. N., Kallel, N., Millet, L., Stock, A., Turon, J. L., and Wirth, S.: North-south palaeohydrological contrasts in the central Mediterranean during the Holocene: tentative synthesis and working hypotheses, Clim. Past Discuss., 9, 1901-1967, doi:10.5194/cpd-9-1901-2013, 2013.

Magri, D.: Late Quaternary vegetation history at Lagaccione near Lago di Bolsena (central Italy), Review Rev. Palaeobot. Palynol., 106, 171-208., 1999.

Magri, D. and Sadori, L.: Late Pleistocene and Holocene pollen stratigraphy at Lago di Vico (central Italy), Veget. Hist. Archaeobot., 8, 247-260, 1999.

Mercuri, A. M., Bandini Mazzanti, M., Florenzano, A., Montecchi, M. C., and Rattighieri, E.: Olea, Juglans and Castanea: The OJC group as pollen evidence of the development of human-induced environments in the Italian peninsula, Quaternary Int., 303, 2442, doi:10.1016/j.quaint.2013.01.005, 2013.

Milliman, J. D. and Syvitski, J. P. M.: Geomorphic/tectonic control of sediment discharge to the ocean: the importance of small mountainous rivers, J. Geol., 100, 525-544, 1992.

Moulin, C., Lambert, C. E., Dulac, F., and Dayan, U.: Control of atmospheric export of dust from North Africa by the North Atlantic Oscillation, Nature, 387, 691-694, 1997.

New, M., Hulme, M., and Jones, P. D.: Representing twentieth century space-time climate variability. Part 2: development of 190196 monthly grids of terrestrial surface climate, J. Climate, 13, 2217-2238, 2000.

Oldfield, F., Asioli, A., Accorsi, C. A., Mercuri, A. M., Juggins, S., Langone, L. Rolph, T., Trincardi, F., Wolff, G., Gibbs, Z., Vigliotti, L., Frignani, M., van der Post, K., and Branch, N.: A high resolution late Holocene palaeoenvironmental record from the central Adriatic Sea, Quatern. Sci. Rev., 22, 319-342, 2003.

Orange, D., Garcia-Garcia, A., Lorenson, T., Nittrouer, C., Milligan, T., Miserocchi, S., Langone, L., Corregiani, A. I., and Trincardi, F.: Shallow gas and flood deposition on the Po Delta, Mar. Geol., 222, 159-177, 2005.

Ortu, E., David, F., and Peyron, O.: Pollen-inferred palaeoclimate reconstruction in the Alps during the Lateglacial and the early Holocene: how to estimate the effect of elevation and local parameters, J. Quat. SCi., 25, 651-661, doi:10.1002/jqs.1335, 2010a.

Ortu, E., Klotz, S., Brugiapaglia, E., Caramiello, R., and Siniscalco, C.: Elevation-induced variations of pollen assemblages in the North-western Alps: An analysis of their value as temperature indicators, Comptes Rendus Biologie, 333, 11-12, doi:10.1016/j.crvi.2010.09.006, 2010b.

Ozenda, P.: Sur les étages de végétation dans les montagnes du bassin méditerranéen, Documents de Cartographie Ecologique, 16, 1-32, 1975.

Palinkas, C. M. and Nittrouer, C. A.: Clinoform sedimentation along the Apennines shelf, Adriatic Sea, Mar. Geol., 234, 245260, 2007.

Petschick, R.: MacDiff v 4.2.5 (Free Geological Software), available at: http://www.geol-pal.unifrankfurt.de/Staff/Homepages/ Petschick/classicsoftware.html\#MacDiff (last access: 2 July 2012), Geologisch-Palaontologisches Institut, Universitat Frankfurt/Main, 2001.

Peyron, O., Guiot, J., Cheddadi, R., Tarasov, P., Reille, M., de Beaulieu, J. L., Bottema, S., and Andrieu, V.: Climatic reconstruction in Europe for 18,000 yr B.P. from pollen data, 
Quaternary Res., 49, 183-196, 1998.

Peyron, O., Goring, S., Dormoy, I., Kotthoff, U., Pross, J., de Beaulieu, J. L., Drescher-Schneider, R., Vannière, B., and Magny, M.: Holocene seasonality changes in central Mediterranean reconstructed from Lake Accesa and Tenaghi Philippon pollen sequences, Holocene, 21, 131-146, 2011.

Peyron, O., Magny, M., Goring, S., Joannin, S., De Beaulieu, J. L., Brugiapaglia, E., Sadori, L., Garfi, G., Kouli, K., Ioakim, C., and Combourieu-Nebout, N.: Contrasting patterns of climatic changes during the Holocene in central Mediterranean area (Italy) reconstructed from pollen data, Clim. Past., 9, 1233-1252, doi:10.5194/cp-9-1233-2013, 2013.

Piva, A., Asioli, A., Trincardi, F., Schneider, R. R., and Vigliotti, L.: Late-Holocene climate variability in the Adriatic Sea (Central Mediterranean), Holocene, 18, 153-167, 2008.

Polunin, O.: Flowers in Greece and the Balkan, a field guide, Oxford Univ. Press, 1980.

Poulain, P. M.: Adriatic Sea surface circulation as derived from drifter data between 1990 and 1999, Mar. Syst., 29, 3-32, 2001.

Prospero, J. M.: Arid regions as sources of minerals aerosols in the marine atmosphere, Geo. S. Am. S, 186, 71-86, 1981.

Pross, J., Kotthoff, U., Müller, U. C., Peyron, O., Dormoy, I., Schmiedl, G., Kalaitzidis, S., and Smith, A. M.: Massive perturbation in terrestrial ecosystems of the Eastern Mediterranean region associated with the 8.2 kyr B.P. climatic event, Geology, 37, 887-890, 2009.

Pye. K.: Aeolian dust and dust deposits, New-York, London, Academic Press, 334 pp., 1987.

Rasmussen, S. O., Vinther, B. M., Clausen, H. B., and Andersen, K.K.: Early Holocene climate oscillations recorded in three Greenland ice cores, Quaternary Sci. Rev., 26, 1907-1914, 2007.

Ravazzi, C.: Late Quaternary history of spruce in southern Europe, Rev. Palaeobot. Palynol., 120, 131-177, 2002.

Rea, D. K., Leinen, M., and Jacenek, T. R.: Geologic approach to the long-term history of atmospheric circulation, Science, 227, 721-725, 1985

Reimer, P. J., Baillie, M. G. L., Bard, E., Bayliss, A., Beck, J. W., Bertrand, C. J. H., Blackwell, P. G., Buck, C. E., Burr, G. S., Cutler, K. B., Damon, P. E., Edwards, R. L., Fairbanks, R. G., Friedrich, M., Guilderson, T. P., Hogg, A. G., Hughen, K. A., Kromer, B., McCormac, F. G., Manning, S. W., Ramsey, C. B., Reimer, R. W., Remmele, S., Southon, J. R., Stuiver, M., Talamo, S., Taylor, F. W., van der Plicht, J., and Weyhenmeyer, C. E.: IntCal04 Terrestrial radiocarbon age calibration, 26-0 ka BP, Radiocarbon, 46, 1029-1058, 2004.

Revel, M., Ducassou, E., Grousset, F., Bernasconi, S. M., Migeon, S., Revillon, S., Mascle, J., Murat, A., Zaragosi, S., and Bosch, D.: 100000 years of African monsoon variability recorded in sediments of the Nile margin, Quaternary Sci. Rev., 29, 1342-1362, 2010.

Rodriguez, S., Querol, X., Alastuey, A., Kallos, G., and Kakaliagou, O.: Saharan dust contributions to PM10 and TSP levels in Southern and Eastern Spain, Atmos. Environ., 35, 2433-2447, 2001.

Sadori, L. and Narcisi, B.: The postglacial record of environmental history from Lago di Pergusa (Sicily), Holocene, 11, 655-671, 2001.

Sadori, L., Jahns, S., and Peyron, O.: Mid-Holocene vegetation history of the Central Mediterranean, Holocene, 21, 117-129, 2011.
Sadori, L., Ortu, E., Peyron, O., Zanchetta, G., Vannière, B., Desmet, M., and Magny, M.: The last 7 millennia of vegetation and climate changes at Lago di Pergusa (central Sicily, Italy), Clim. Past Discuss., 9, 2059-2094, doi:10.5194/cpd-92059-2013, 2013.

Schmiedl, G., Kuhnt, T., Ehrmann, W., Emeis, K., Hamann, Y., Kotthoff, U., Dulski, P., and Pross, J.: Climatic forcing of eastern Mediterranean deep-water formation and benthic ecosystems during the past 22000 years, Quatern. Sci. Rev., 29, 3006-3020, 2010.

Siani, G., Paterne, M., Arnold, M., Bard, E., Metivier, B., Tisnerat, N., and Bassinot, F.: Radiocarbon reservoir ages in the Mediterranean Sea and Black Sea coastal waters, Radiocarbon, 42, 271 280, 2000.

Siani, G., Paterne, M., Michel, E., Sulpizio, R., Sbrana, A., Arnold, M., and Haddad, G.: Mediterranean Sea surface radiocarbon reservoir age changes since the Last Glacial Maximum, Science, 294, 1917-1920, doi:10.1126/science.1063649, 2001.

Siani, G., Sulpizio, R., Paterne, M., and Sbrana, A.: Tephrostratigraphy study for the last $18,000{ }^{14} \mathrm{C}$ years in a deep-sea sediment sequence for the South Adriatic, Quaternary Sci. Rev., 23, 24852500, 2004.

Siani, G., Paterne, M., and Colin, C.: Late glacial to Holocene planktic foraminifera bioevents and climatic record in the South Adriatic Sea, J. Quaternary Sci., 25, 808-821, 2010.

Siani, G., Magny, M., and Paterne, M.: Impact of the Holocene climate variability on the Adriatic paleohydrology, Clim. Past, 9, 499-515, doi:10.5194/cp-9-499-2013, 2013.

Sicre, M.-A., Siani, G., Genty, D., Kallel, N., and Essallami, L.: Seemingly divergent sea surface temperature proxy records in the central Mediterranean during the last deglaciation, Clim. Past, 9, 1375-1383, doi:10.5194/cp-9-1375-2013, 2013.

Sjögren, P., Knaap, W. V. D., Huusko, A., and Leeuwen, J. F. V.: Pollen productivity, dispersal, 22 and correction factors for major tree taxa in the Swiss Alps based on pollen-trap results, Rev. Palaeobot. Palynol., 152, 200-210, 2008.

Sorgente, D.: Studio della sedimentazione attuale e recente nel medio Adriatico attraverso l'uso di traccianti redioattivi, Ph.D. Thesis, University of Bologna, 178 pp., 1999.

Ter Braak, C. J. F. and Juggins, S.: Weighted averaging partial least squares regression (WA-PLS): An improved method for reconstructing environmental variables from species assemblages, Hydrobiologia, 269/270, 485-502, 1993.

Tomadin, L.: Sedimentary fluxed and different dispersion mechanism of the clay sediments in the Adriatic Basin, Rend. Fis. Acc. Lincei, 9, 161-174, 2000.

Tomadin, L. and Lenaz, R.: Eolian dust over the Mediterranean and their contribution to the present sedimentation, in: Paleoclimatology and Paleometeorology: modern and past patterns of global atmospheric transport, edited by: Leinen, M. and Sarnthein, M., Dordrecht, Kluwer academic, 282, 267-281, 1989.

Torres-Padrón, M. E., Gelado-Caballero, M. D., Collado-Sánchez, C., Siruela-Matos, V. F., Cardona-Castellano, P. J., and Hernández-Brito, J. J.: Variability of dust inputs to the CANIGO zone, Deep-Sea Res. II, 49, 3455-3464, 2002.

Turon, J.-L.: Le palynoplancton dans l'environnement actuel de l'Atlantique nord-oriental. Evolution climatique et hydrologique depuis le dernier maximum glaciaire, $\mathrm{PhD}$ thesis, Bordeaux 1 University, France, 1984. 
Tzedakis, P. C.: Seven ambiguities in the Mediterranean palaeoenvironmental narrative, Quaternary Sci. Rev., 26, 2042-2066, 2007. van der Knaap, W. O., van Leeuwen, J. F. N., Finsinger, W., Gobet, E., Pini, R., Schweizer, A., Valsecchi, V., and Ammann, B.: Migration and population expansion of Abies, Fagus, Picea, and Quercus since 15,000 years in and across the Alps, based on pollen-percentage threshold values, Quaternary Sci. Rev., 24, 645-680, 2005.

Walker, M. J. C., Berkelhammer, M., Björck, S., Cwynar, L. C., Fisher, D. A., Long, A. J., Lowe, J. J., Newnham, R. M., Rasmussen, S. O., and Weiss, H.: Formal subdivision of the Holocene Series/Epoch: a Discussion Paper by a Working Group of INTIMATE (Integration of ice-core, marine and terrestrial records) and the Subcommission on Quaternary Stratigraphy (International Commission on Stratigraphy), J. Quaternary Sci., 27, 640-659, 2012.

Walter, W., Harnickell, E., and Mueller-Dombois, D.: Climate DiagramMaps, Springer-Verlag, 1975.

Watts, W. A., Allen, J. R. M., and Huntley, B.: Vegetation history and palaeoclimate of the Last Glacial period at Lago Grande di Monticchio, Southern Italy, Quaternary Sci. Rev., 15, 133-153, 1996.
Wheatcroft, R. A., Nittrouer, C. A., Miserocchi, S., and Trincardi, F.; A comparison of recent floods and flood deposits of the Eel and Po Rivers, in: American Geophysical Union - Chapman conference: Formation of sedimentary strata on continental margins, Puerto Rico, 17-19 June, 2001.

Woodward, F. I.: Climate and plant distribution, Cambridge Univ. Press, Cambridge, England, 1987.

Wu, H., Guiot, J., Brewer, S., and Guo, Z.: Climatic changes in Eurasia and Africa at the last glacial maximum and mid-Holocene: reconstruction from pollen data using inverse vegetation modelling, Clim. Dynam., 29, 211-229, doi:10.1007/s00382-007-0231-3, 2007.

Zanchettin, D., Traverso, P., and Tomasino, M.: Po River discharges: a preliminary analysis of a 200 -year tile series, Clim. Change, 89, 411-433, 2008.

Zhornyak, L. V., Zanchetta, G., Drysdale, R. N., Hellstrom, J. C., Isola, I., Regattieri, E., Piccini, L., Baneschi, I., and Couchoud, I.: Stratigraphic evidence for a "pluvial phase" between ca. 8200-7100 ka from Renella cave (Central Italy), Quaternary Sci. Rev., 30, 409-417, 2011. 